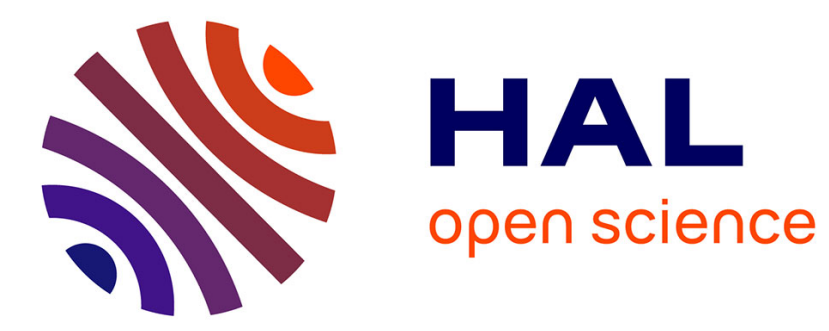

\title{
Biological responses to contaminants in the Humber Estuary: Disentangling complex relationships
}

J. García-Alonso, G.M. Greenway, A. Munshi, J.C. Gómez, K. Mazik, A.W. Knight, J.D. Hardege, M. Elliott

\section{- To cite this version:}

J. García-Alonso, G.M. Greenway, A. Munshi, J.C. Gómez, K. Mazik, et al.. Biological responses to contaminants in the Humber Estuary: Disentangling complex relationships. Marine Environmental Research, 2011, 71 (4), pp.295. 10.1016/j.marenvres.2011.02.004 . hal-00682419

HAL Id: hal-00682419 https://hal.science/hal-00682419

Submitted on 26 Mar 2012

HAL is a multi-disciplinary open access archive for the deposit and dissemination of scientific research documents, whether they are published or not. The documents may come from teaching and research institutions in France or abroad, or from public or private research centers.
L'archive ouverte pluridisciplinaire HAL, est destinée au dépôt et à la diffusion de documents scientifiques de niveau recherche, publiés ou non, émanant des établissements d'enseignement et de recherche français ou étrangers, des laboratoires publics ou privés. 


\section{Accepted Manuscript}

Title: Biological responses to contaminants in the Humber Estuary: Disentangling complex relationships

Authors: J. García-Alonso, G.M. Greenway, A. Munshi, J.C. Gómez, K. Mazik, A.W. Knight, J.D. Hardege, M. Elliott

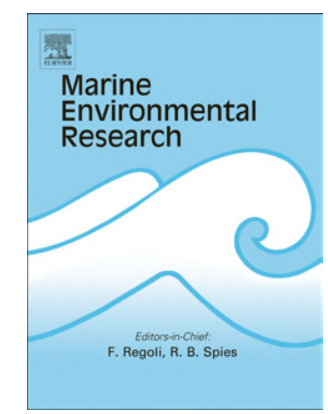

PII: S0141-1136(11)00025-0

DOI: 10.1016/j.marenvres.2011.02.004

Reference: MERE 3510

To appear in: Marine Environmental Research

Received Date: 13 November 2010

Revised Date: 10 February 2011

Accepted Date: 11 February 2011

Please cite this article as: García-Alonso, J., Greenway, G.M., Munshi, A., Gómez, J.C., Mazik, K., Knight, A.W., Hardege, J.D., Elliott, M. Biological responses to contaminants in the Humber Estuary: Disentangling complex relationships, Marine Environmental Research (2011), doi: 10.1016/ j.marenvres.2011.02.004

This is a PDF file of an unedited manuscript that has been accepted for publication. As a service to our customers we are providing this early version of the manuscript. The manuscript will undergo copyediting, typesetting, and review of the resulting proof before it is published in its final form. Please note that during the production process errors may be discovered which could affect the content, and all legal disclaimers that apply to the journal pertain. 
Biological responses to contaminants in the Humber Estuary: disentangling complex relationships

García-Alonso, J., ${ }^{\mathrm{a} \mathrm{g}^{*}}$, Greenway, G.M. ${ }^{\mathrm{b}}$, Munshi A. ${ }^{\mathrm{b}, \mathrm{c}}$, Gómez, J.C. ${ }^{\mathrm{d}}$, Mazik K. , Knight, A.W. ${ }^{\mathrm{f}}$, Hardege, J.D. ${ }^{\mathrm{g}}$ and Elliott, M. ${ }^{\mathrm{e}}$

${ }^{\text {a }}$ Department of Zoology, Natural History Museum, London SW7 5BD, England.

${ }^{\mathrm{b}}$ Department of Chemistry, University of Hull, Hull, HU6 7RX, England.

${ }^{c}$ Centre of Environmental Studies, PCSIR, Karachi, 75280, Pakistan.

${ }^{\mathrm{d}}$ UNDECIMAR, Universidad de la República, Montevideo 11400, Uruguay.

${ }^{\mathrm{e}}$ Institute of Estuarine \& Coastal Studies, University of Hull, Hull, HU6 7RX, England.

f Gentronix Limited CTF Building, 46 Grafton Street, Manchester, M13 9NT, England.

${ }^{\mathrm{g}}$ Department of Biological Sciences, University of Hull, Hull, HU6 7RX, England.

* Corresponding Author: Present Address - Department of Zoology, Natural History Museum, Cromwell Road, SW7 5BD, London Tel ++44-2079426685 Fax ++442079425054 j.garcia-alonso@nhm.ac.uk 


\section{Abstract}

Due to the ecological importance of estuaries, it is necessary to understand the biological effects that potentially toxic contaminants induce in bioindicator species. A key aspect is whether effects at lower levels of biological organisation transfer through the system to higher levels. In understanding such processes, characterising multivariate relationships between contaminants, sediment toxicities and detoxification processes are important. Worms (Hediste diversicolor) and sediments were collected along the Humber Estuary, England, and inorganic and organic contaminants were quantified. Sediment toxicities and glutathione S-transferases (GSTs) activity in the ragworm were analysed. Concentrations of metals were highest near urban and industrial areas, whereas organic contaminants appeared at upstream locations. GST activity correlated with heavy metals. The genotoxicity, estrogenicity, dioxin and dioxin-like activity were higher at upstream locations. Estrogenicity correlated with alkylphenols and some organochlorines, whilst genotoxicity correlated with organochlorines and heavy metals. Despite this, higher level biological responses could not be predicted, indicating that homeostasis is operating.

Key Words: Trace metals; organic pollutants; GST; sediment toxicity; environmental homeostasis; Humber estuary 


\section{Introduction}

Estuaries are highly productive ecosystems, important nursery and recruitment areas for many species and support dense populations of invertebrates, which act as key prey species for higher animals (McLusky and Elliott, 2004; Dauvin, 2008). As they are characterised by fine grained and organic rich sediments, they act as sink for contaminants and they are therefore priority areas for identifying potential bioindicator species and biomarkers of pollution (Ducrotoy, 2010).

Direct and diffuse (agricultural and urban run-off, riverine inputs) inputs to catchments have long degraded estuarine ecosystems worldwide. Many key contaminants such as metals, organochlorines and endocrine disrupting chemicals are well-characterised and increasingly regulated and monitored, thus the occurrence of lethal toxic effects and a number of higher level sub-lethal effects, such as severe impacts on reproductive success, are now rare. However, much less is known about combined effects of mixtures of contaminants at the biochemical and molecular level in relation to chronic, lower level exposure, and the link between these effects and those at higher ecological levels (i.e. populations, communities and ecosystems). Previously it has been assumed that an impact on the lower levels of biological organisation (the cell and individual) would, if the stressor had not been removed or reduced, been transferred through to higher ecological levels (Lawrence and Hemingway, 2003). However, it is now hypothesised that because of the system complexity, changes at lower levels may get absorbed through the system or the organisms could accommodate the changes such that there are no concomitant changes at higher levels - a feature described at environmental homeostasis (Elliott and Quintino, 2007). It was suggested by Elliott and Quintino that estuaries are environmentally variable and their organisms adapted to that variability such that 
stress is more difficult to detect in whole estuarine systems. Hence there is a need to disentangle these factors when assessing environmental impacts.

Several metals and metalloids are known to produce oxidative stress with biological effects such as lipid peroxidation and genotoxicity (Bocchetti et al., 2004, Sun and Zhou, 2008). Metals, and other persistent contaminants, often bio-accumulate and may bio-magnify through the food chain with the potential to affect human health (McLusky and Elliott, 2004, Luoma and Rainbow, 2008). Stable synthetic organic compounds are considered persistent, bioaccumulative and toxic contaminants (PBT). Among them, xeno-estrogens, nonylphenols (NP), octylphenol (OP) and bisphenol A (BPA) and organochlorines (PCBs and some pesticides) may also act as endocrine disruptors (EDCs) at concentrations found in estuarine systems (Lutz and Kloas, 1999). They are also oxidative stressors and genotoxic to many organisms (Nice et al., 2003).

Species respond specifically to these challenges with different mechanisms of detoxification that can in turn be used as biomarkers. Detoxification enzymes are used widely to detect pollution in aquatic environments, and include the glutathione-stransferases (GSTs) which comprising a superfamily of multifunctional proteins with fundamental roles in the detoxification of a wide range of compounds (Frova, 2006, Davies, 1985, Bainy et al., 2000). Additionally, peroxidase and isomerase activities have been described for GST enzymes, enabling their use as biomarkers for oxidative stress (Sheehan et al., 2001). GST has been employed in biomonitoring and impact assessments of heavy metals, organic contaminants including EDCs (Pérez-López, et al., 2002, Martín-Díaz et al. 2008, Moreira et al., 2006, Berglund et al., 2007, Solé et al., 2009). In polychaetes, the use of GST as a biomarker of oxidative stress has been demonstrated in Hediste (Nereis) diversicolor in Portuguese (Moreira et al., 2006) and 
French estuaries (Durou et al., 2007), and in the exposure of Alitta (Nereis) succinea to copper (Rhee et al., 2007) and to the xeno-estrogen nonylphenol (Ayoola et al., 2010). The ragworm $H$. diversicolor was used as a sentinel species in the present study given its success as an estuarine species as shown by large and widespread populations in European estuaries and its previously reported use as a biomarker (Pocklington and Wells, 1992, Poirier et al., 2006, Sun and Zhou, 2008). As they have a variable feeding mode covering both deposits and suspensions, they are exposed to and can bio-concentrate and bio-accumulate persistent contaminants (Gray and Elliott, 2009).

Inorganic and organic contaminants in sedimentary sinks reflect inputs to the aquatic environment. However, the partitioning in surface waters shows that the concentration of metals and the hydrophobic organic compounds in particulate material exceed the water soluble concentration by orders of magnitude (Luoma and Rainbow, 2008). Sediments from both the catchment and the sea accumulate at the mouth of rivers and in estuaries, which become sinks for such toxic chemicals. Fine sediments accumulate and create organic films, which also attract and accumulate contaminants (Gray and Elliott, 2009), thus estuarine organisms are assumed to be excellent sentinels for pollution detection, in particular those that live at the sedimentwater interface such as the infaunal $H$. diversicolor.

Given the complex nature of these relationships, employing multivariate approaches is essential to link the concentration and composition of contaminants to their individual and synergistic toxicities, detoxification and tolerance in specific environments such as estuaries. This work tests the hypothesis that only an integrative approach can be used to analyse the relationships between the concentration of contaminants, toxicities such as genotoxicity, cytotoxicity, estrogenicity and dioxin- 
like activity in the sediments, and GST activity as a general biomarker of stress; furthermore this approach is required to understand more fully toxic effects and biological responses in complex natural environments. These aspects were analysed in samples obtained from the north shore of the Humber Estuary system in Eastern England.

\section{Materials and Methods}

\subsection{Humber as a case study area}

The Humber Estuary, Eastern England (UK) is one of the largest basins in the British Isles with a key role in bird conservation (Archer, 2000). It has historically received industrial and urban waste from a large catchment area (Jaffe and Walters, 1977, Oguchi et al., 2000) and its sediments have a relatively uniform grain size and chemical composition, including some metals (Grant and Middleton, 1993).

\subsection{Sample collection}

Sediment samples and worms were collected from 12 sampling points covering 4 different zones along the north bank of the Humber Estuary (Figure 1): Kilnsea (1, 2 and 3) located downstream close to the mouth of the estuary; Paull (4, 5 and 6) and Hessle (7, 8 and 9) close to urban and industrial zones and Blacktoft (10, 11 and 12) at the confluence of River Ouse with the Humber. The 3 sampling points at each site may be regarded as field replicates.

Samples were taken during the low tide in the upper intertidal zone during May 2007. The upper $5 \mathrm{~cm}$ layer of brownish oxidised sediment and ragworms were transported in a cool box at $8^{\circ} \mathrm{C}$ to the University of Hull. Sediments were dried and stored at $-20^{\circ} \mathrm{C}$. Worms ( $H$. diversicolor) were dried with absorbent paper, weighed, 
fast frozen in liquid nitrogen and stored at $-80{ }^{\circ} \mathrm{C}$ until analysis. Sediment organic content was measured as percentage loss on ignition (dry sediment kept at $550{ }^{\circ} \mathrm{C}$ for 3 hours). Salinity was obtained from measuring sodium ( $\mathrm{Na}$ ) concentration by optical emission spectroscopy (Optima 5300DV, Perkin Elmer) in dry sediment. Sediment moisture was calculated and concentration of $\mathrm{Na}$ per interstitial water volume was estimated.

\subsection{Trace elements analysis}

The sediment samples were dried at $60{ }^{\circ} \mathrm{C}$ for 72 hours before being ground and sieved (100 $\mu \mathrm{m}$ mesh size) and $1 \mathrm{~g}$ of each sample was taken for extraction in 55 ml PFA Teflon digestion vessels with $10 \mathrm{ml}$ nitric acid in a microwave digestion system (MARS Xpress), heated at $200{ }^{\circ} \mathrm{C}$ for $15 \mathrm{~min}$. The digests were then analysed using an optical emission spectrometer- mass spectrometer (OES-MS). The concentrations of the elements in the digests were calculated in the original dry solid in $\mu \mathrm{g} \mathrm{g}^{-1}$ of sediment.

\subsection{Organic contaminants}

The organochlorines (PCBs and pesticides) and the xeno-estrogens, nonylphenol, octylphenol and bisphenol A (BPA) were extracted from the sediments using Sohxlet apparatus and analysed by gas chromatography electron capture detector (GC-ECD) and GC-mass spectrometry (GC-MS). Organochlorine standards (Mix 71) and individual PCBs standards were purchased from Dr. Ehrenstofer Laboratories, Germany and Accute Standards, USA. Nonylphenol (technical mixture isomers), octylphenol $99 \%$, Bisphenol A 99+ \%, the internal standard 4-(3,6- 
dimethyl-3-heptyl)phenol (ring- $\left.{ }^{13} \mathrm{C}_{6}\right)^{\mathrm{b}} \quad([13 \mathrm{C} 6]-363 \mathrm{NP})$ and derivatising agent MSTFA, were obtained from Sigma-Aldrich, Poole, UK.

The determination of PCBs and organochlorines was according to Munshi et al. (2004). Sediment samples (25 g) were extracted with acetone:hexane (1:1 v/v, 250 ml) during 8 hours. Extracts were analyzed using a GC (Perkin Elmer Clarus 500) equipped with an ECD, using a DB-5 column (30 m x $250 \mu \mathrm{m} \times 0.25 \mu \mathrm{m})$. The detection limit (LD) for pesticides and PCBs was $5 \mathrm{ng} \mathrm{g}^{-1}$ dry weight.

Determination of xeno-estrogens was according to Ayoola et al. (2010) adapted for sediments. Five grams of sediment was spiked with $100 \mu$ l of internal standard ([13C6]-363 NP) and extracted with $90 \mathrm{ml}$ hexane:isopropanol (85:15, v:v) during 6 hours at $60{ }^{\circ} \mathrm{C}$. Samples were evaporated, re-dissolved in $200 \mu 1$ of acetone and derivatised with $25 \mu \mathrm{l}$ of MSTFA at room temperature. A sample volume of $1 \mu \mathrm{l}$ was injected into the GC-MS for analysis using an Agilent 6890N gas chromatograph directly connected to an Agilent 5973 inert mass selective detector in a selective ion mode (SIM). In most cases, the recoveries of detected organic pollutants ranged between 80 and $98 \%$. The DL were 3.1 and $2.2 \mathrm{ng} \mathrm{g}^{-1}$ dry weight fro OP and NP respectively.

\subsection{Genotoxicity and cytotoxicity assay - GreenScreen GC ${ }^{\mathrm{TM}}$}

Genotoxicity was assessed using the GreenScreen $\mathrm{GC}^{\mathrm{TM}}$ assay from Gentronix Ltd. which uses a DNA repair-competent strain of the yeast Saccharomyces cerevisiae. The reporter consisted of a fusion of the DNA damage-inducible promoter from an endogenous DNA repair gene, RAD54, with a gene encoding a yeast enhanced green fluorescent protein (yEGFP). RAD54 is known to be specifically upregulated by the cells in response to DNA damage, and thus on exposure to a 
genotoxic agent the cells become increasingly fluorescent as GFP accumulates. Simultaneously cytotoxicity was assessed by the reduction in cell proliferation during incubation compared to a vehicle-treated control. Cell density was quantified by optical absorbance. Methyl methanesulfonate (MMS, Sigma Aldrich) was used as a genotoxic standard, methanol was used as a cytotoxic standard and $2 \%$ (aq.) DMSO (for molecular biology, Sigma Aldrich) was used as the diluent for all samples and standards. The protocol has been previously reported (Cahill et al., 2004). In brief, sediment samples were dried at $60{ }^{\circ} \mathrm{C}$ and $200 \mathrm{mg}$ was re-suspended with $1 \mathrm{ml} 100 \%$ dimethyl sulfoxide (DMSO), vigorously vortexed 3 times for 5 min and centrifuged at 8000 g. $40 \mu \mathrm{l}$ of DMSO solution was transferred to a tube containing $960 \mu 1$ of double distilled water. Extracts were added to the yeast in proprietary growth media at serial dilution in a 96 well microplate, together with the standard chemicals and vehicletreated controls, incubated overnight ( $16-20$ hours) and then optical absorbance (450 $\mathrm{nm}$ ) and fluorescence (excitation $485 \mathrm{~nm}$, emission $510 \mathrm{~nm}$ ) were monitored using a microplate reader POLARstar OPTIMA (BMG Labtech, UK). Fluorescence and optical absorbance data were processed using Excel based software provided by Gentronix. The LEC (lowest effective concentration) in $\mathrm{g} \mathrm{ml}^{-1}$ is the lowest test concentration at which the significance threshold for genotoxicity or cytotoxicity is exceeded.

\subsection{CALUX assays}

Estrogenicity $\quad\left(\right.$ ER-Calux $\left.^{\circledR}\right)$ and Dioxin-like activity (DR Calux ${ }^{\circledR}$ ) measurements were performed according to Houtman et al. (2006). Sediments were dried and then $5 \mathrm{~g}$ extracted using an accelerated solvent extraction system with 100 $\mathrm{ml}$ hexane/acetone. A concentration series of $\mathrm{E}_{2}$ ( for ER-CALUX) or 2,3,7, 
8-tetrachlorodibenzo-p-dioxin (TCDD, for DR-CALUX) was employed as standards and the analyses were performed in the BioDetection Systems laboratories (Amsterdam, Netherlands). Sediments were extracted, desulphurised and cleaned up prior to analysis, and then dissolved in DMSO and the activity determined after 24 hours exposure. Measurements were in pg EEQ $\mathrm{g}^{-1}$ of sediment for ER-CALUX and as polychlorinated dibenzofurans (PCDD/F)-PCBs-toxic equivalent quantity (TEQ) $\mathrm{g}^{-}$ ${ }^{1}$ for DR-CALUX.

\subsection{GST activity analysis and protein quantification}

One gram of worms (10 worms of approximate $100 \mathrm{mg}$ each) per sampling point was homogenized using an ultrasonicator (Soniprobe, 7533A) in cold buffer solution (100 mM potassium phosphate buffer, $\mathrm{pH}$ 6.5, containing $2 \mathrm{mM}$ EDTA). The tissue homogenates were immediately centrifuged at $15,000 \mathrm{~g}$ for $15 \mathrm{~min}$. at $4{ }^{\circ} \mathrm{C}$. The supernatants were collected and aliquots of the supernatants were stored at $-80{ }^{\circ} \mathrm{C}$ prior to use. The protein extracts were used to quantify the GST activity and normalised with the total protein concentration calculated using the Bradford method with bovine serum albumin as a standard.

The activity of GST was determined according to the method developed by Habig et al. (1974), adapted to a microplate reader. In brief, this involves measuring the increment in absorbance generated by the conjugation of 1-chloro-2,4dinitrobenzene with reduced glutathione in the presence of GSTs at $340 \mathrm{~nm}$ using a microplate reader. Dulbecco phosphate buffer saline, $2 \mathrm{mM}$ reduced glutathione and 1 $\mathrm{mM}$ 1-chloro-2, 4-dinitrobenzene were added to the aliquots and the enzyme activity was recorded by following the rate of change in optical absorbance $\left(\min ^{-1}\right)$ at $340 \mathrm{~nm}$ 
for 5 min. GST from equine liver (Sigma-Aldrich, \#G6511) was employed as a positive control. The results were calculated in $\mathrm{nmol} \mathrm{min}^{-1} \mathrm{mg}^{-1}$ of protein.

\subsection{Statistical analysis}

The variables were regarded as environmental (independent) factors (locality, salinity and organic matter), inorganic contaminants (metals and metalloids), organochlorines (principally pesticides), xeno-estrogens (OC, NP and BPA) and the potential dependent (biological response) variables (GST activity in H. diversicolor, dioxin and dioxin-like activity, estrogenicity, genotoxicity and cytotoxicity). Initially the intra- and inter-group correlations (using two-tailed Pearson test) were obtained between the independent variable groups using the following factors: distance downstream, salinity and organic matter content (after testing for normality). The linear and non-linear relationships were explored to determine which of the variables were correlated with, and thus be responsible for, the sediment chemistry/contaminants/biological response data. Principal component analysis (PCA) was performed to identify relationships between GST activity, sediment toxicity, organic matter content and salinity, related to each specific group of contaminants according to chemical similarity. After obtaining a main factor representing the contaminants with major effects in the total variance, the factor coordinates of cases, based on covariance, were also correlated with biological effects. In general, a linear model was used by default and quadratic relationships were used when these models explained more than $20 \%$ of the variance in comparison to the linear models. Exploratory correlation analyses and multivariate analysis (PCA) were performed using SPSSv17 and PRIMERv6 (Clarke and Gorley, 2006). Given that all the variables have had different units, these were standardised 
and normalised using the Brodgar formula, according to Zurr et al., (2007) before plotting the PCA. GST activity in $H$. diversicolor from different locations in the Humber Estuary was compared by one-way analysis of variance (ANOVA) followed by Tukeys test post-hoc comparisons after prior normalisation using logtransformation (significant level $\mathrm{p}<0.05$ ).

\section{Results}

The organic content in the sediments ranged between 6.31 (location 9) and 10.79 $\%$ (location 3) representing relatively little difference between locations. Salinity range were from 1.96 to 19.78 at the most downstream location (table 1S). The abundance and the variability (max. and min. values) of each contaminant analysed are also shown in Table S1. The 14 PCB congeners analysed were below the detection limit $(<\mathrm{DL})$ so were not significantly higher than the blanks. In addition, several organochlorine compounds were below the limit of detection (Quintozene; Heptachlor exo-epoxide; Heptachlor endo-epoxide; alpha-Endosulfan and beta-Endosulfan).

\subsection{Element traces in sediments}

The relative abundance of the elements analysed was: $\mathrm{Al}>\mathrm{Zn}>\mathrm{Pb}>\mathrm{Cr}>\mathrm{Cu}>\mathrm{Ni}>>\mathrm{Co}>\mathrm{As}>\mathrm{Cd}$. The relative distributions of almost all elements were positively correlated thus showing similar distributions and accumulation in the sediments (Fig. S1).

Several elements showed their highest values in mid-estuary locations (corresponding to Paull and Hessle) and thus the quadratic model provides a good fit to their data. Hence the elements show a quadratic pattern in relation to the locations, 
and although they did not correlate with the interstitial salt concentration, in most cases they were positively correlated with organic matter content (Fig. 2).

\subsection{Organic contaminants}

Almost all organochlorines analysed were found being positively correlated, indicating a similar distribution and accumulation process (Fig. S2). Endrin and Aldrin showed the highest concentrations being found in upstream locations at $201 \pm$ 9.5 and $127 \pm 4.5 \mathrm{ng} \mathrm{g}^{-1}$ respectively. In relation to environmental parameters, organochlorine distributions differed, some in relation to distance and therefore salinity, whilst other pesticides correlated well with the organic matter content (Fig. 3). For instance, the antifungal hexachlorobenzene was concentrated in downstream sediments, alpha $\mathrm{HCH}$ was higher at middle stream locations, whilst all other organochlorines were present at their highest concentrations in the upstream locations (Fig. 3).

As with some organochlorines, xeno-estrogens were more abundant in the sediments at the upstream locations. Concentrations of alkylphenols (NP and OP) were also higher at the upstream points and were therefore negatively correlated with salinity and interesting, with organic matter content (Fig. 4). NP was detected at a maximum concentration of $1.29 \mu \mathrm{g} \mathrm{g}^{-1}$ while $\mathrm{OP}$ at the same location was at $0.38 \mu \mathrm{g}$ $\mathrm{g}^{-1}$. BPA was detected at lower concentrations (highest value was $0.038 \mu \mathrm{g} \mathrm{g}^{-1}$ ) and close or below the limit of detection in the other sampling locations (Table S1).

The potential toxic elements and the organic contaminants were in general negatively associated with each other or no relationship was observed (Fig. S3).

\subsection{Glutathioine-S-transferase (GST) activity in $\boldsymbol{H}$. diversicolor}


The GST activity in worms differed with locations with those at Paull (downstream of the city of Hull) showing the highest values of $56.27 \pm 6.23 \mathrm{nmol}$ $\min ^{-1} \mathrm{mg}^{-1}$ of protein which were significantly different (One way ANOVA, $\mathrm{F}_{(3,11)}=$ $6.029, p<0.05)$ from other zones of the estuary. The lowest values were close to the mouth of the estuary (Kilnsea, locations 1 to 3 ) with $41.21 \pm 2.17 \mathrm{nmol} \mathrm{min}{ }^{-1} \mathrm{mg}^{-1}$ of protein. Moreover, the GST activity showed a positive correlation with As and $\mathrm{Cu}$ (Fig. 6).

\subsection{Sediment toxicity}

In general, sediment toxicity was higher at upstream locations, except for cytotoxicity which was highest in sediments in downstream areas (Fig. 5). Genotoxicity clearly increased towards upstream locations with no genotoxicity being detected in the most downstream points (Fig. 5). Upper-Middle locations 7 to 9 (Hessle) showed the highest response and the LEC was $1.3 \mathrm{mg}$ of sediment per $\mathrm{ml}$ of culture, and also higher in the upstream locations 10 to 12 (Blacktoft), the LEC value was $2.5 \mathrm{mg} \mathrm{ml}^{-1}$. However, the stations 4 to 6 (Paull) close to industrial sources showed the lowest genotoxicity $\left(\mathrm{LEC}=5.0 \mathrm{mg} \mathrm{ml}^{-1}\right)$. Cytotoxicity was highest in samples from station 3 (Kilnsea) and, in contrast to the genotoxicity results, in downstream sediments ( $\mathrm{LEC}=1.3 \mathrm{mg} \mathrm{ml}^{-1}$ in both cases). Low cytotoxicity was detected in the upstream location $\left(\mathrm{LEC}=2.5 \mathrm{mg} \mathrm{ml}^{-1}\right)$ and Paull $\left(\mathrm{LEC}=5 \mathrm{mg} \mathrm{ml}^{-1}\right)$, indicating higher cytotoxicity in the outer estuary, although the absolute values indicate that the cytotoxicity is relatively low throughout the Humber without any correlation with environmental variables (Fig. 5).

The estrogenicity of sediments also varied among the locations. Mid and upstream locations (Hessle and Blacktoft) showed the highest values with 320 and 346 pg EEQ 
$\mathrm{g}^{-1}$ of sediment respectively, while sediments from Kilnsea and Paull showed 191 and $171 \mathrm{pg} \mathrm{EEQ} \mathrm{g}^{-1}$ of sediment respectively. No correlation was observed with organic matter content (Fig. 5).

The DR-CALUX test showed a very low response at all locations, suggesting no significant dioxin-like pollution in sediments of the Humber Estuary and reflecting the low levels of PCBs measured in the sediments. Upstream sediments (Blacktoft and Hessle) showed the highest dioxin and dioxin-like PCB response, which negatively correlated with salinity (Fig. 5). Samples from Hessle had the highest value 71 pg PCDD/F-PCB-TEQ $\mathrm{g}^{-1}$ of sediment and Blacktoft 52 pg PCDD/F-PCB-TEQ g ${ }^{-1}$ of sediment while Paull and Kilnsea showed 23 and 25 pg PCDD/F-PCB-TEQ g $^{-1}$ respectively. None of the biological responses were associated with the organic matter content (Fig. 5).

\subsection{Relationship between contaminants, sediment toxicities and detoxification in}

\section{H. diversicolor}

Given the spatial complexity in the contamination and biological response variables described above, it is necessary to interrogate the interrelationships. There were no other relationships between toxicities and metals/metalloids other than a positive correlation of $\mathrm{As}$ and $\mathrm{Cu}$ with the GST activity. It is of note that none of the organic contaminants analysed in this study showed significant correlations with the GST activity in ragworms (Fig. 6). The PCA plot suggests that Alpha-HCH and the expected heavy metals appeared associated with GST activity (Fig. 7). The organochlorines (i.e. aldrin, dieldrin and the factor coordinates of cases of the main factor obtained on the PCA of total organochlorines) correlate with genotoxicity (Fig 
6 and 7). In relation to estrogenicity, aldrin, dieldrin, endrin, alkylphenols (NP and OP) and the factor coordinates of cases of the main factor obtained on the PCA of total organochlorines and xeno-estrogens correlated well (Fig. 6) and are very consistent with the multivariate analysis (Fig. 7).

Analysing the combined effect of all the contaminants together with the GST activity (PCA) and sediment toxicity, the main component was found to be determined by two clear groups: trace metals and the organic contaminants, with some exceptions such as $\mathrm{HCB}$ and Apha-HCH which are involved in explaining the second component (Fig. 7). The biological responses found in worms and sediments suggest potential synergism or additive response of some contaminants explained with the main component such as genotoxicity, DR-Calux and ER-Calux (Fig 7). These results suggest a possible interaction between the different chemicals and thus specific biological responses depending on the prevailing contaminant regime. Furthermore, the distribution for some chemicals were not related to any environmental parameters measured in this work, indicating the general uniformity of the physico-chemical characteristics of the macrotidal Humber estuary.

\section{Discussion}

In this study, most of the inorganic contaminants in sediment samples were in general at low concentrations and the sum of all elements analysed was similar to those found in clean British estuaries and lower compared with historically polluted ones (Bryan et al., 1985). The low level of PCBs and the distribution confirmed previous work on PCBs in the Humber estuary (Tyler and Millward, 1996). Organochlorine pesticides were all at trace levels and low amounts of xeno-estrogens were detected (Table S1). 
However, significantly higher GST activities in $H$. diversicolor were found at stations 4 to 6 corresponding to Paull area, indicating the bioavailability of xenobiotics and a potential toxicity on ragworms. Our results (Fig. 6 and 7) suggest that metals such as $\mathrm{Cu}$ could be directly related to this biological response.

The highest percentages of organic matter in the intertidal mudflat corresponded to mid- and down estuary locations, especially those at Kilnsea at Spurn (near the mouth of the estuary) and Hessle where there is a creek (Haven) coming from an urbanised area. The mudflats are wider here reflecting a less energetic water flux on the upper shore compared to the steeper, narrower mudflats in the upper estuary. Several elements correlated with the organic matter content of the sediments, although (Fig. 2). In particular, dissolved $\mathrm{Cu}$ and $\mathrm{Cd}$ have high affinity for sewage-derived particulate matter (Comber et al., 1995) and are expected to increase its concentration in organic-rich sediments.

The upper limit for copper was $62.6 \mu \mathrm{g} \mathrm{g}^{-1}$, corresponding to a moderately-high contaminated range (50-200 $\mu \mathrm{g} \mathrm{g}^{-1}$ ) according to Luoma and Rainbow (2008). Concentrations of $\mathrm{Cd}$, which is a toxic and genotoxic element, were elevated (up to $9.35 \mu \mathrm{g} \mathrm{g}^{-1}$ ) when compared with other British estuaries (Luoma and Rainbow, 2008 after Bryan et al., 1985). Due to its increasing use, it is not unexpected to find elevated concentrations of $\mathrm{Cd}$ in estuarine sediments. The concentrations observed here are higher than those measured in British estuaries 20 years ago (see Luoma \& Rainbow, 2008) and specifically for the Humber, the uniform distribution of metals described previously for intertidal sediments (Grant and Middleton, 1993) has been modified over the past 2 decades. In addition, water samples from the Humber Estuary presented the highest concentration of $\mathrm{Cd}$ with an average of $0.08 \mu \mathrm{g}^{-1}$ in 
subsurface waters of British estuaries (Law et al., 1994) and similar concentration of Cd was determined in surface waters (Comber et al., 1995). The highest concentration of elements analysed in sediments were found in mid-estuary locations (Paull and Hessle) suggesting the proximity to contaminant inputs and/or settlement and sink areas. The presence of quadratic models rather than linear models indicates, for example, that in relation to the locations, there is either a potential point source within the area or a differential accumulation along the estuary's north bank (Fig. 2).

Concentrations of $\mathrm{Zn}$ appeared significantly higher in mid-estuary locations and could reflect discharges from both current and past industrial activity, which is the main source of $\mathrm{Zn}$ in estuarine sediments (Joslin, 2000, Luoma and Rainbow, 2008). $\mathrm{Zn}$ is used worldwide for its corrosion-resistance properties on ferrous metals implicating its anthropogenic distributions (Gordon et al., 2003). However the absolute concentration values do not represent a contaminated system as occurred in other historical polluted estuaries (Luoma and Rainbow, 2008). Two potential toxic elements (As and $\mathrm{Cu}$ ) appeared related to GST activity in ragworms (Fig. 6) suggesting be stressors that can increase the GST activity in polychaetes.

The bioavailability and therefore the toxicity of metals decreases with an increasing salinity and an increase in oxic properties of the sediments (McLusky et al., 1986, Du Laing et al., 2008) so toxic effects of metal traces are more likely in upstream sediments compared to the marine-influenced zone. Since the distribution of most of the elements analysed occurred in middle locations of the Humber, no correlation were observed with salinity (Fig. 2).

Humber sediments are dominated by silicate clay minerals that readily adsorb part of the organic fraction including many contaminants (Jarvie et al., 1997). Organic contaminants such as organochlorines, have a greater ability to adsorb to the organic 
fraction than to the clays, therefore we expected to find higher concentration of the congeners which contain more $\mathrm{Cl}^{-}$ions, since they are more hydrophobic. Many pesticides are organochlorine compounds which are PBT chemicals. Endrin and Aldrin, both now banned substances, were the most abundant organochlorines found in upstream locations suggesting an input coming from past agricultural activity in the catchment (Table S1, Fig. 3).

Xeno-estrogens appeared at moderate levels in comparison to other estuarine sediment analysed (Bennett and Metcalfe, 1998Kawahata et al., 2004). As expected, the strongest estrogenic compounds OP and NP, correlated well with the estrogenicity of the sediments (Fig. 6). Although estrogenic signalling have been clearly observed in nereid polychaetes (García-Alonso et al. 2006, Durou and Mouneyrac, 2007, Keay and Thornton, 2009) and that xeno-estrogens induced GST in a closely related species (N. succinea, Ayoola et al., 2010) GST activity did not correlated with xeno-estrogen in $H$. diversicolor on this study.

Genotoxicity appeared higher at mid-estuary (Hessle) and upstream locations (Blacktoft) with an LEC of 0.0013 and $0.0025 \mathrm{~g} \mathrm{ml}^{-1}$ respectively, decreasing along the sampling sites until no genotoxicity was observed in downstream points (Paull and Kilnsea). This may be the result of a pool of inorganic and organic contaminants as suggested in Fig. 7; further chemical analyses are required to better understand this sediment toxicity.

Whilst the present study has quantified the concentrations of metal ions, and these include metal ions with known genotoxic and carcinogenic properties (i.e. chromium, as dichromate, nickel and cadmium), there is limited direct correlation between genotoxic activity and the concentration of any particular metal or combinations of metal ions. Since sediments are complex mixtures, simple correlations between 
mutagenic potential and the presence and concentrations of known sample components are often not possible since genotoxicity arises through the synergistic activity of several contaminants present in low concentration, or through complex interactions between contaminants. The GreenScreen GC assay clearly discriminates between cytotoxic and genotoxic endpoints and has been shown to demonstrate a high specificity in the assessment of genotoxicity, i.e. samples do not produce a positive result for genotoxicity in this assay as a result of cytotoxicity alone (Cahill et al., 2004). Genotoxic contaminants can arise from a number of anthropogenic sources and include diverse organic chemicals such as organochlorine pesticides from agrochemical run off (Bull et al., 2006, Poletta et al., 2009) among other chemicals (Claxton et al., 1998, White and Rasmussen, 1998). In addition, dredging should also be considered as sediments which are re-located within the estuary may contain historic contamination which is re-liberated and re-distributed around the system (Gray and Elliott, 2009).

Dioxin activity is present in the Humber sediments at very low level. Even though, there is a clear gradient of response - suggesting that this assay could also respond to furans or dioxins, which were not measured in this work. Estrogenicity was positively associated with the concentrations of NP and OP but not with BPA which is a weak estrogenic chemical (Fig. 6 and 7). Also, estrogen responses appear associated with pesticides such as aldrin, eldrin and dieldrin (Fig. 6), which may have some effects in activation of the estrogen receptor transcription factor.

The Humber estuary has been shown to be moderately polluted with $\mathrm{Cu}$ and $\mathrm{As}$ which levels have been reported to induce certain tolerance in $H$. diversicolor (Nedwell, 1997, Jones et al., 2000). Accordingly, the GST activity was highest in 
worms at the mid-estuary points $(p<0.05)$ in contrast to the upstream and downstream sites. This detoxification activity appeared very well associated with the concentration of metals in general, includings $\mathrm{Cu}$ and $\mathrm{As}$ (Fig. 8). $\mathrm{Cu}$ was found at toxic level in Paull, and is a well known oxidative stressor. Moreover,. Rhee et al. (2007) demonstrated that concentration as low as $12 \mu \mathrm{g} \mathrm{l} \mathrm{l}^{-1}$ of $\mathrm{CuCl}_{2}$ induces the activity of GST in nereids. Cu appeared at a toxic level in mid-estuary sites, reaching an average of $55.5 \mu \mathrm{g} \mathrm{g}^{-1}$ supporting the hypothesis of metals as an oxidative stressor in $H$. diversicolor. The multivariate approach advocated here describing the association of contaminants and GST confirms the individual correlation with $\mathrm{Cu}$ and As in the mid-estuary locations, but also a pool of metal and Alpha $\mathrm{HCH}$ contaminants could explain an additive effect in the deteoxification response of the worms by GST (Fig. 7).

In particular, the cytotoxicity of sediments is the most intriguing characteristic even though and it is not clearly related to any of the individual contaminants analysed here. Given the distinction between contamination (as enhanced levels of substances) and pollution (implying a biological health response) (McLusky and Elliott, 2004) then cytotoxicity of sediments is of high relevance here despite not being related to any single contaminant analysed here. Biological effects observed in the field (i.e. de facto pollution), the association with their cause (de facto contaminants) and the link with subtle ecological consequences are poorly understood or lacking completely, including in very well studied estuarine systems (Langston et al. 2010). As shown here, despite the presence of well-studied contaminants, the specific pollutant responses should occur but often do not, as the case of some metals and genotoxicity in this work. Similarly, locations which had specific pollutant responses were not contaminated by potential pollutants such as Dioxin-like 
substances and PCBs. Hence this implies that often, the different approaches could give false positive results, that the responses are not sufficiently strong or that the complex system has the ability to absorb the change, i.e. environmental homeostasis (Elliott and Quintino, 2007). The latter suggests the ecosystem has the ability to absorb changes such that changes at the genetic or cellular levels do not follow through the system and do not lead to higher level changes at the individual, population or community levels. If the system can be subject to a stressor but there is no resulting effect at higher biological levels then the system has absorbed the stress ergo environmental homeostasis (Elliott and Quintino, 2007).

Consequently, we can indicate the sequence of changes at the lower levels of biological organisation based on the results here to show the relationship between contaminants and toxicities from our results and the potential outcome. Despite this, it is not yet possible to show the consequences of these at the higher levels of biological organisation. The presence of differential biological responses to the presence of contaminants along the estuary may have some influence on population tolerance, survival or adaptation (e.g. GST activity) and these harmful effects produced by contamination, and thus constituting de facto pollution, should be included in environmental risk assessments. For example, there are small areas of the Humber where the benthic communities are impoverished as a direct result of industrial discharge (e.g. Mazik and Elliott, 2000). Such severe impacts are highly localised and there have been significant efforts (through the Environment Agency's Review of Consents) to improve effluent quality throughout the estuary in order to further minimise or eliminate such impacts (Mazik and Elliott, 2007).

To date, no links have been found between cellular, genetic or biochemical responses and population/community level responses. As such, there is no way of 
knowing whether the apparently healthy invertebrate communities in the Humber are functioning normally or whether their ability to grow and reproduce has been jeopardised as a result of exposure to contaminants. Similarly, there is no information regarding the degree of lower level biological responses which may have led to population and community changes in areas of high impact. An understanding of this would greatly increase the value of biochemical and molecular methods of detecting biological response to pollution and would give these assays greater meaning as early warning indicators of higher level impacts.

In conclusion, the concentrations of contaminants found in the upper intertidal sediments appear to be related to different biological responses. The highest concentrations of toxic metals were found in the sediments close to industrial and urban areas. $\mathrm{Cu}$ was present at toxic levels in some areas and $\mathrm{Cd}$ appeared at relatively high levels in the sediments. The biomarker of exposure, the GST activity, used in detoxification processes was significantly higher in worms in certain sites and appears to be affected by the presence of some metals such as $\mathrm{Cu}$. Of course other chemicals not analysed here, could be involved in the sediment toxicities and further interrogation of correlations between contaminants and toxicities (Fig. 10) will investigate the cause-effect relationships and indicate which chemicals and synergisms or additive responses could be involved in different types of toxicities in estuarine sediments.

\section{Acknowledgments}

The authors would like to thank H Besselink (BDS B.V. Amsterdam) for ER-Calux and DR-Calux assays, R Knight for metal analysis and Dr Z Velez for helping in field 
sampling. This work was partially funded by the University of Hull and by European Commission, TESS COLL-CT-2006 project ( $6^{\text {th }}$ Framework Programme).

\section{Electronic Supplementary material}

A summary of the concentrations of inorganic and organic pollutants measured (Table S1). The correlations between inorganic pollutants (Fig. S1). The correlations between organochlorines (Fig. S2) and the correlations between inorganic and organic pollutants (Fig. S3).

\section{References}

Archer, R., 2000. The Humber Estuary - an internationally important bird area. In: N.V. Jones, M. Elliott (Editors), Coastal Zone Topics: Process, Ecology \& Management, Volume 4. The Humber Estuary and adjoining Yorkshire and Lincolnshire Coasts. Estuarine \& Coastal Sciences Association, Hull, UK, pp. $117-124$.

Ayoola, J.A.O., García-Alonso, J., Hardege, J.D., 2010. Xenoestrogen induces stress in Nereis succinea (Polychaeta) and affect the reproductive fitness. Environmental Toxicology (DOI: 10.1002/tox.20580).

Bainy, A.C.D., Almeida, E.A., Muller, I.C., Ventura, E.C., Medeiros, I.D., 2000. Biochemical responses in farmed mussels Perna perna transplanted to contaminated sites on Santa Catarina Island, SC, Brazil. Marine Environmental Research 50, 503-508.

Bennett, E.R., Metcalfe, C. D., 1998. Distribution of alkylphenol compounds in Great Lakes sediments, United States and Canada. Environ. Toxicol. Chem. 17, 1230-1235. 
Berglund, A.M.M., Sturve, J., Förlin, L., Nyholm, N.E.I., 2007. Oxidative stress in pied flycatcher (Ficedula hypoleuca) nestlings from metal contaminated environments in northern Sweden. Environmental Research 105, 330-339.

Bocchetti, R., Fattorini, D., Gambi, M. C., Regoli, F., 2004. Trace Metal Concentrations and Susceptibility to Oxidative Stress in the Polychaete Sabella spallanzanii (Gmelin) (Sabellidae): Potential Role of Antioxidants in Revealing Stressful Environmental Conditions in the Mediterranean. Archives Environmental Contamination Toxicology 46, 353-361.

Bryan, G.W., Langston, W.J., Hummerstone, L.G., Burt, G.R., 1985. A guide to the assessment of heavy-metal contamination in estuaries. Occasional Publications of the Marine Biological Association of the United Kingdom 4, 92 pp.

Bull, S., Fletcher, K., Boobis, A.R., Battershill, J.M., 2006. Evidence for genotoxicity of pesticides in pesticides applicators: a review. Mutagenesis 21, 93-103.

Cahill, P.A., Knight, A.W., Billinton, N., Barker, M.G., Walsh, L., Keenan, P.O., Williams, C.V., Tweats, D.J., Walmsley, R.M., 2004. The GreenScreen genotoxicity assay: a screening validation. Mutagenesis 19, 105-119.

Clarke, K.R., Gorley, R.N. 2006. Primer v6: User manual/tutorial. Primer E Ltd.

Claxton, L.D., Houk, V.S., Hughes, T.J., 1998. Genotoxicity of industrial wastes and effluents. Mutation Research 410, 237-243.

Comber, S.D.W., Gunn, A.M., Whalley, C., 1995. Comparison of the partitioning of trace metals in the Humber and Mersey estuaries. Marine Pollution Bulletin $30,851-860$.

Dauvin, J-C., 2008. Effects of heavy metal contamination on the macrobenthic fauna of estuaries: the case of the Seine. Marine Pollution Bulletin 57, 160-169. 
Davies, P.E., 1985. The toxicology and metabolism of chlorothalonil in fish. III. Metabolism, enzymatics and detoxication in Salmo spp. and Galaxias spp. Aquatic Toxicology 7, 277-299.

Ducrotoy, J-P., 2010. The use of biotopes in assessing the environmental quality of tidal estuaries in Europe. Estuarine, Coastal and Shelf Science 86, 317-321.

Du Laing, G., De Vos, R., Vandecasteele, B., Lesage, E., Tack, F.M.G., 2008. Effect of salinity on heavy metal mobility and availability in intertidal sediments of the Scheldt estuary. Estuarine, Coastal and Shelf Science 77, 589-602.

Durou, C., Mouneyrac, C., 2007. Linking steroid hormone levels to sexual maturity index and energy reserves in Nereis diversicolor from clean and polluted estuaries. General and Comparative Endocrinology 150, 106-113.

Durou, C., Poirier, L., Amiard, J.C., Budzinski, H., Gnassia-Barelli, M., Lemenach, K., Peluhet, L., Mouneyrac, C., Roméo M., Amiard-Triquet, C., 2007. Biomonitoring in a clean and a multi-contaminated estuary based on biomarkers and chemical analyses in the endobenthic worm Nereis diversicolor. Environmental Pollution 148, 445-458.

Elliott, M., Quintino, V., 2007. The Estuarine Quality Paradox, Environmental Homeostasis and the difficulty of detecting anthropogenic stress in naturally stressed areas. Marine Pollution Bulletin 54, 640-645.

Elliott, M., Hemingway, K.L., Krueger, D., Thiel, R., Hylland, K., Arukwe, A., Förlin, L., Sayer, M., 2003. Chapter 6: Links between the individual response and the population and community response to pollution. In: (Eds.: Lawrence, A.J. \& K.L. Hemingway) Effects of Pollution on Fish. Blackwell Science Ltd., Oxford. 
Frova, C., 2006. Glutathione transferases in the genomics era: New insights and perspectives. Biomolecular Engineering 23,149-169.

García-Alonso, J., Hoeger, U., Rebscher, N., 2006. Regulation of vitellogenesis in Nereis virens (Annelida: Polychaeta): Effect of estradiol-17b on eleocyte. Comparative Biochemistry and Physiology A 143, 55-61.

Gordon, R.B., Graedel, T.E., Bertram, M., 2003. The characterization of technological zinc cycles. Resources, Conservation and Recycling 39, 107135.

Grant, A., Middleton, R., 1993. Trace metals in sediments from the Humber estuary: A statistical analysis of spatial uniformity. Netherlands Journal of Aquatic Ecology 27(2-4), 111-120.

Gray, J.S., Elliott, M., 2009. Ecology of marine sediments: From Science to management, second edition. Oxford University Press, Oxford.

Habig, W.H., Pabst, M.J., Jakoby, B., 1974. Glutathione-S-transferase: The first enzymatic step in mercapturic acid formation. Journal of Biological Chemistry 249, 7130-7139.

Houtman, C.J., Booij, P., Jover, E., Pascual del Rio, D., Swart, K., van Velzen, M., Vreuls, R., Legler, J., Brouwer, A., Lamoree, M.H., 2006. Estrogenic and dioxin-like compounds in sediment from Zierikzee harbour identified with CALUX assay-directed fractionation combined with one and two dimensional gas chromatography analyses. Chemosphere 65, 2244-2252.

Jaffe, D., Walter, J.K., 1977. Intertidal trace metal concentrations in some sediments from the Humber estuary. Sciences of the Total Environment 7, 1-15.

Jarvie, H.P., Neal, C., Robson, A.J., 1997. The geography of the Humber catchment. Science of The Total Environment 194-195, 87-99. 
Jones, N.V., Nedwell, S., Sahu, A.K., Vowles, S.E., 2000. Humber invertebrates and their responses to heavy metals. In: N.V. Jones, M. Elliott (Editors), Coastal Zone Topics: Process, Ecology \& Management, Volume 4. The Humber Estuary and adjoining Yorkshire and Lincolnshire Coasts. Estuarine \& Coastal Sciences Association, Hull, UK, pp. 67-71.

Joslin, M.T., 2000. BP Chemicals and the Humber: The role, responsibilities and activities of a major estuarine industrial user. In: N.V. Jones, M. Elliott (Editors), Coastal Zone Topics: Process, Ecology \& Management, Volume 4. The Humber Estuary and adjoining Yorkshire and Lincolnshire Coasts. Estuarine \& Coastal Sciences Association, Hull, UK, pp. 49-51.

Kawahata, H., Ohta, H., Inoue, M., Suzuki, A., 2004. Endocrine disruptor nonylphenol and bisphenol A contamination in Okinawa and Ishigaki Islands, Japan-within coral reefs and adjacent river mouths. Chemosphere 55, $1519-27$.

Keay, J., Thornton, J.W., 2009. Hormone-activated estrogen receptors in annelid invertebrates: implications for evolution and endocrine disruption. Endocrinology 150, 1731-1738.

Langston, W.J., Pope, N.D., Jonas, P.J.C., Nikitic, C., Field, M.D.R., Dowell, M., Shillabeer, N., Swarbrick, R.H., Brown, A.R., 2010. Contaminants in fine sediments and their consequences for biota of the Severn Estuary. Marine Pollution Bulletin 61, 68-82.

Lawrence, A.J., Hemingway, K.L. (Eds.) 2003. Pollution in Fishes. Blackwell Publ., Oxford. 
Law, R.J., Waldock, M.J., Allchin, C.R., Laslett, R.E., Bailey, K.J., 1994. Contaminants in seawater around England and Wales: Results from monitoring surveys, 1990-1992. Marine Pollution Bulletin 28, 668-675.

Luoma, S.N., Rainbow, P.S., 2008. Metal contamination in aquatic environments: Science and lateral management. Cambridge (UK), Cambridge Univ, pp. 573.

Lutz, I., Kloas, W., 1999. Amphibians as model to study endocrine disruptors: I. Environmental pollution and estrogen receptor binding. Science of the Total Environment . 225, $49-57$.

Martín-Díaz, M.L., J. Blasco, J., Sales, D., Delvalls, T.A., 2008. Field validation of a battery of biomarkers to assess sediment quality in Spanish ports. Environmental Pollution 151, 631-640.

Mazik, K., Elliott, M., 2000. The effects of chemical pollution on the bioturbation potential of estuarine intertidal mudflats. Helgoland Marine Research 54, 99109.

Mazik, K., Elliott, M., 2007. Environmental Impact Assessment for the Killingholme Refinery discharge. Institute of Estuarine \& Coastal Studies report to ConocoPhillips. Report No. ZBB679-F-2006a.

McLusky, D.S., Elliott, M., 2004. The Estuarine Ecosystem; ecology, threats and management, 3 rd Edn. OUP, Oxford.

McLusky, D.S., Bryant, V., Campbell, R., 1986. The effects of temperature and salinity on the toxicity of heavy metals to marine and estuarine invertebrates. Oceanography and Marine Biology 24, 481-520.

Moreira, S.M., Lima, I., Rubeiro, R., Guilhermino, L., 2006. Effects of estuarine sediment contamination on feeding and on key physiological functions of 
polychaete Hediste diversicolor: Laboratory and in situ assays. Aquatic Toxicology 78, 187-201.

Munshi, A.B., Schulz, Bull, D., Schneider, R., Zuberi, R., 2004. Organochlorine concentration in various fish from different locations of Karachi coast. Marine Pollution Bulletin. 49(7-8), 597-601.

Nedwell, S.F., 1997. Intraspecific variation in the responses to copper by two estuarine invertebrates. Unpublished PhD thesis, University of Hull, 123pp.

Nice, H.E., Morritt, D., Crane, M., Thorndyke, M., 2003. Long-term and transgenerational effects of nonylphenol exposure at a key stage in the development of Crassostrea gigas. Possible endocrine disruption? Marine Ecology Progress Series 256, 293-300.

Oguchi, T., Jarvie, H.P., Neal, C., 2000. River water quality in the Humber catchment: an introduction using GIS-based mapping and analysis. Science of the Total Environment 251/252, 9-26.

Pérez-López, M., Nóvoa Valiñas, M.C., Melgar Riol, M.J., 2002. Induction of cytosolic Glutathione-S-transferase from Atlantic eel (Anguilla anquilla) after intraperitoneal treatment with polychlorinated biphenyls. Science of the Total Environment 297, 141-151.

Pocklington, P., Wells, P.G., 1992. Polychaetes: key taxa for marine Environmental quality monitoring. Marine Pollution Bulletin 24, 593-598.

Poletta, G.L., Larriera, A., Kleinsorge, E., Mudry, M.D., 2009. Genotoxicity of the herbicide formulation roundup (glyphosate) in broad-snouted caiman (Caiman latirostris) evidenced by the comet assay and the micronucleus test. Mutation Research 672, 95-102. 
Poirier, L., Berthet, B., Amiard, J., Jeantet, A., Amiard-Triquet, C., 2006. A suitable model for the biomonitoring of trace metal bioavailabilities in estuarine sediments: the annelid polychaete Nereis diversicolor. Journal of the Marine Biological Association of the UK 86, 71-82.

Rhee, J., Lee, Y., Hwang, D., Lee, K., Kim, C., Shin, K., Raisuddin, S., Lee, J., 2007. Molecular cloning and characterization of omega class glutathione Stransferase (GST-O) from the polychaete Neanthes succinea: Biochemical comparison with theta class glutathione S-transferase (GST-T). Comparative Biochemistry and Physiology C 146, 471-477.

Sheehan, D., Meade, G., Foley, V.M., Dowd, C.A., 2001. Structure, function and evolution of glutathione transferases: implications for classification of nonmammalian members of an ancient enzyme superfamily. Biochemical Journal $360,1-16$.

Solé, M., Kopecka-Pilarczyk, J., Blasco, J., 2009. Pollution biomarkers in two estuarine invertebrates, Nereis diversicolor and Scrobicularia plana, from a Marsh ecosystem in SW Spain. Environment International 35, 523-531.

Sun, F-H., Zhou, Q-X., 2008. Oxidative stress biomarkers of the polychaete Nereis diversicolor exposed to cadmium and petroleum hydrocarbons. Ecotoxicology and Environmental Safety 70, 106-114.

Turner, A., Millward, G.E., Morris, A.W., 1991. Particulate metals in five major North Sea estuaries. Estuarine, Coastal and Shelf Sciences 32, 325-346.

Tyler, A.O., Millward, G.E., 1996. Distribution and Partitioning of Polychlorinated Dibenzo-p-dioxins, Polychlorinated Dibenzofurans and Polychlorinated Biphenyls in the Humber Estuary, UK. Marine Pollution Bulletin, 32, 397-403. 
White, P.A., Rasmussen, J.B., 1998. The genotoxic hazards of domestic wastes in surface waters. Mutation Research 410, 223-236.

Zurr, A., Ieno, E.N. \& Smith, G. 2007. Analysing Ecological Data. Statistics for biology and health. Springer, New York, 672pp. 


\section{Figure Legends}

Figure 1. Locations of the sediment and ragworm (Hediste diversicolor) samples collected along the north bank of the Humber Estuary. Sampling was carried out at three parallel points at each location.

Figure 2. Relationships between the concentration of metals and metalloids and environmental parameters found in the intertidal sediment of the Humber Estuary. Significant correlations $(\mathrm{p}<0.05)$ are shown with curves. Al, aluminium; As, arsenic; $\mathrm{Cd}$, cadmium; Co, cobalt; $\mathrm{Cr}$, chromium; $\mathrm{Cu}$, copper, $\mathrm{Pb}$, lead; $\mathrm{Zn}$, zinc, Ni, nickel. 'Locations' represents the distance from station 1 (Downstream) to the remaining 11 locations, until location 12 (Upstream). 'Organic matter' is represented as a percentage of the total sediment weight. Significant relationships $(\mathrm{p}<0.05)$ are shown with curves.

Figure 3. Relationships between the concentrations of organochlorines and environmental parameters found in the intertidal sediment of the Humber Estuary. 'Locations' represents the distance from station 1 (Downstream) to the remaining 11 locations, until location 12 (Upstream). 'Organic matter' is represented as percentage of the total sediment weight. Significant relationships $(\mathrm{p}<0.05)$ are shown with curves.

Figure 4. Relationships between the concentration of xeno-estrogens (NP, OP and BPA) and the distances between sampling points, salinity and organic matter content found in the intertidal sediment of the Humber Estuary. NP, nonylphenol; OP, octylphenol; BPA, biphenol A. 'Locations' represents the distance from station 1 
(Downstream) to the remaining 11 locations, until location 12 (Upstream). 'Organic matter' in percentage of the total sediment weight. Significant relationships $(p<0.05)$ are shown with curves.

Figure 5. Toxic responses in relation to environmental parameters. Relationships between the Glutathione-S-transferase (GST) activity in nmol $\mathrm{min}^{-1} \mathrm{mg}^{-1}$ of protein from Nereis diversicolor and sediment toxicities with locations, salinity and organic matter. 'Locations' represents the distance from station 1 (Downstream) to the remaining 11 locations, until location 12 (Upstream). Significant relationships $(\mathrm{p}<$ 0.05) are shown with the best fit correlation curves.

Figure 6. Significant relationships $(\mathrm{p}<0.05)$ between metal concentrations, organochlorine and xeno-estrogens and main component extracted from PCA in sediments vs GST activity in Nereis diversicolor and sediment toxicities from the Humber estuary. OP, octylphenol; NP, nonylphenol. GST, glutathione-S-transferases; F1 Xeno, main factor from PCA of xeno-estrogens; F1 Organo, main factor from PCA of organochlorines.

Figure 7. PCA showing the associations between contaminants (green), biological responses (black) and salinity and organic matter content (blue). Biological responses (GST activity in ragworms and sediment toxicities) are in dashed lines, normalised within the two main components and the contaminants (solid lines) within the two main PCA. Numbers indicate the locations. HCB, hexachlorobenzene; HC, Heptachlor; OP, octylphenol; NP, nonylphenol; BPA, bisphenol A. 
Fig. 1

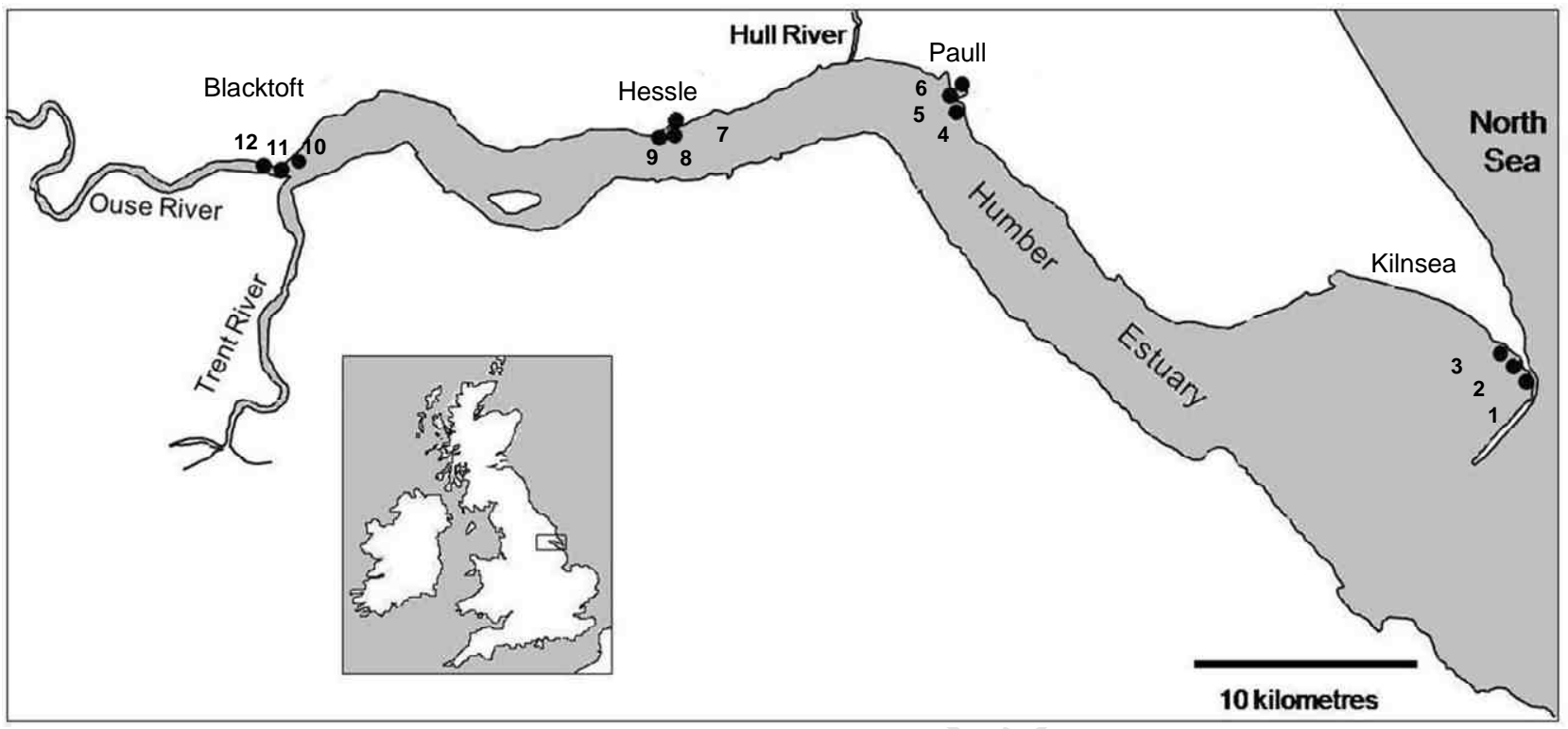


Fig 2

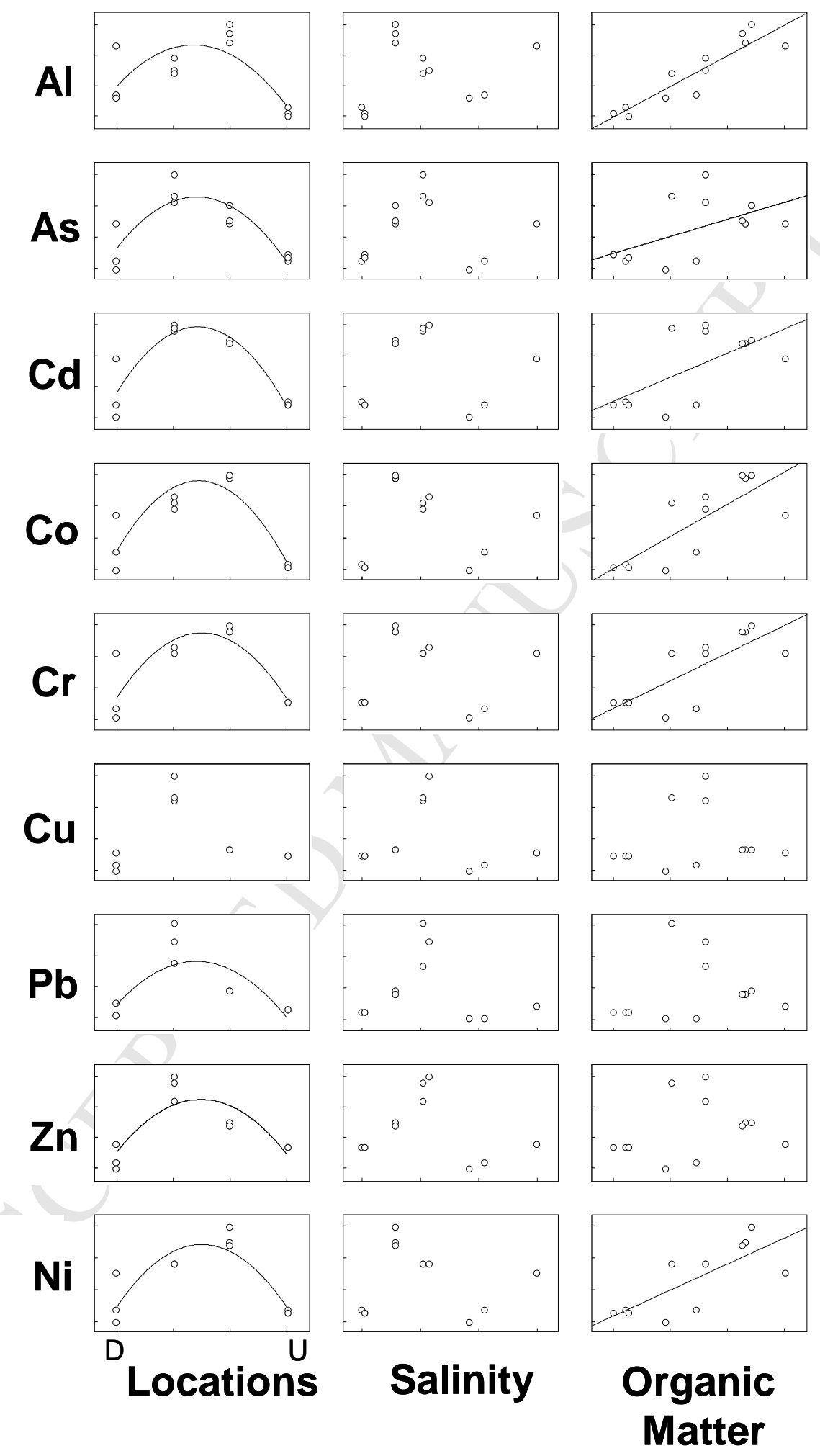


Fig. 3

$\alpha-\mathrm{HCH}$

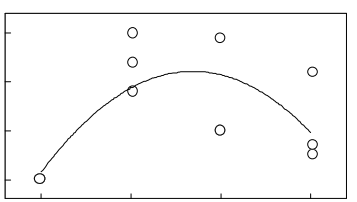

Hexachloro-

benzene
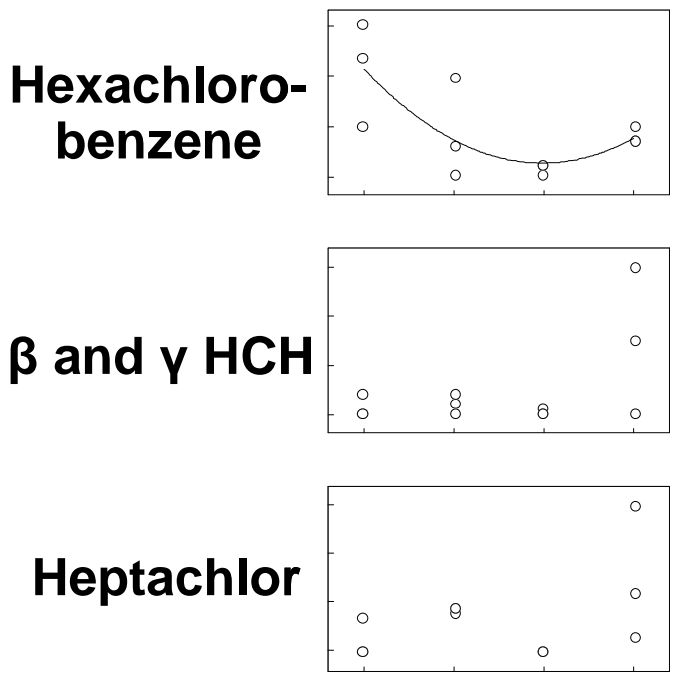

Aldrin

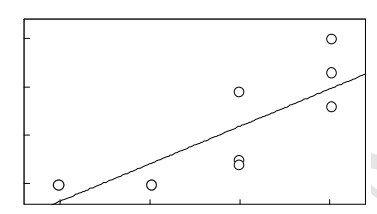

DDE + Dieldrin
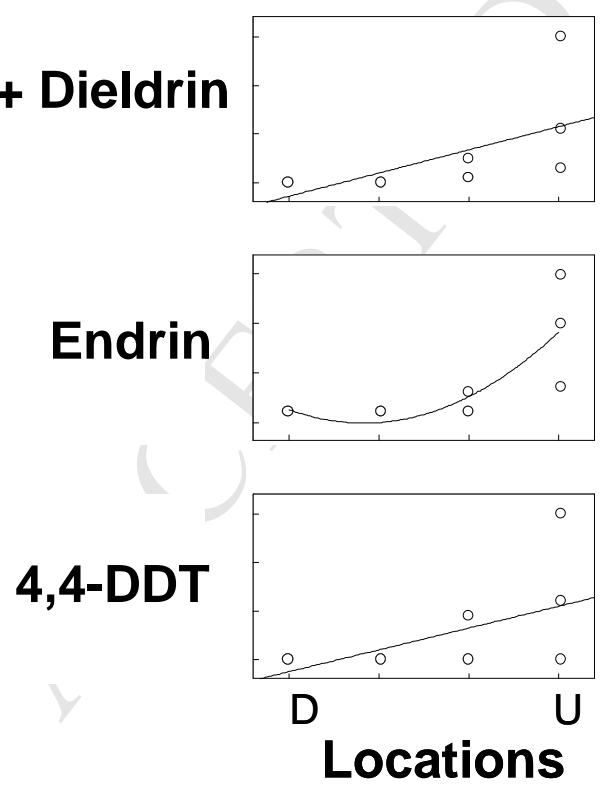
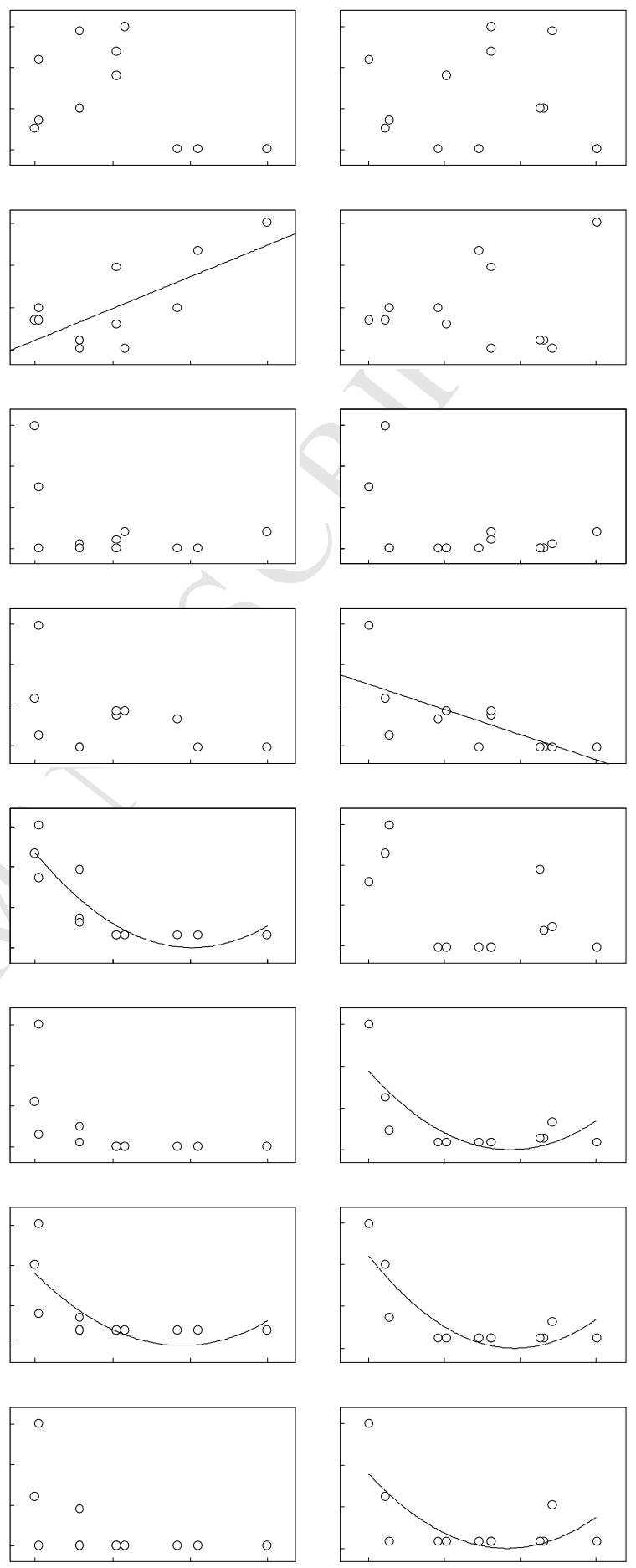

Salinity

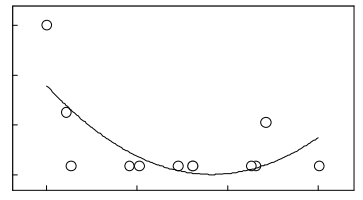

Organic

Matter 
Fig. 4
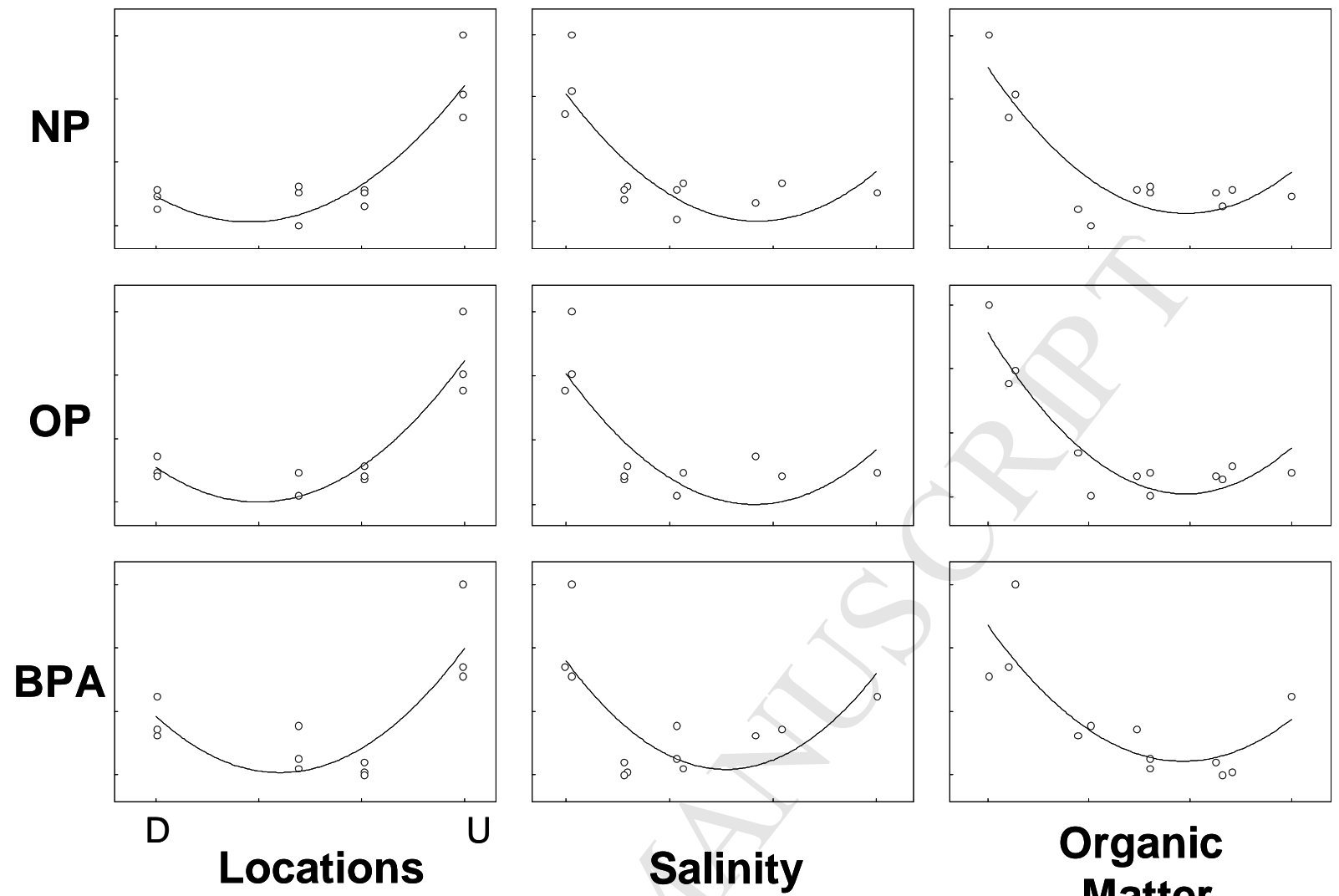

Salinity

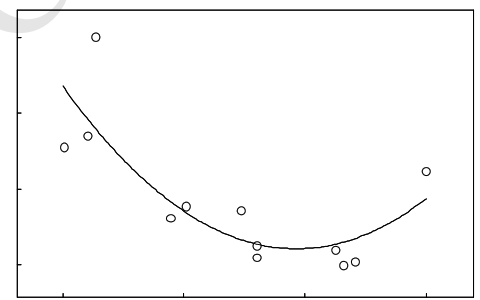

Organic Matter 
Fig. 5
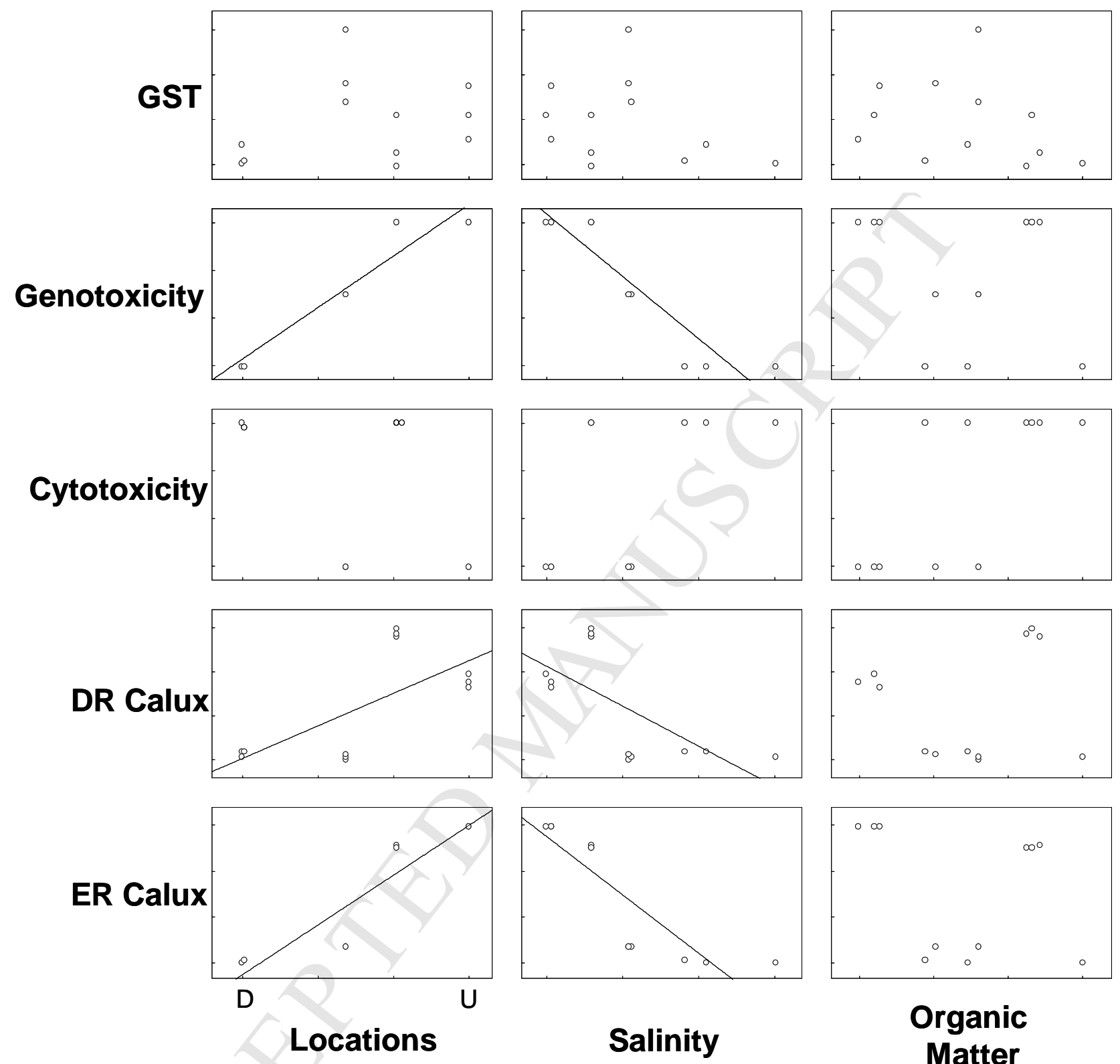

Salinity

Organic Matter 
Fig. 6

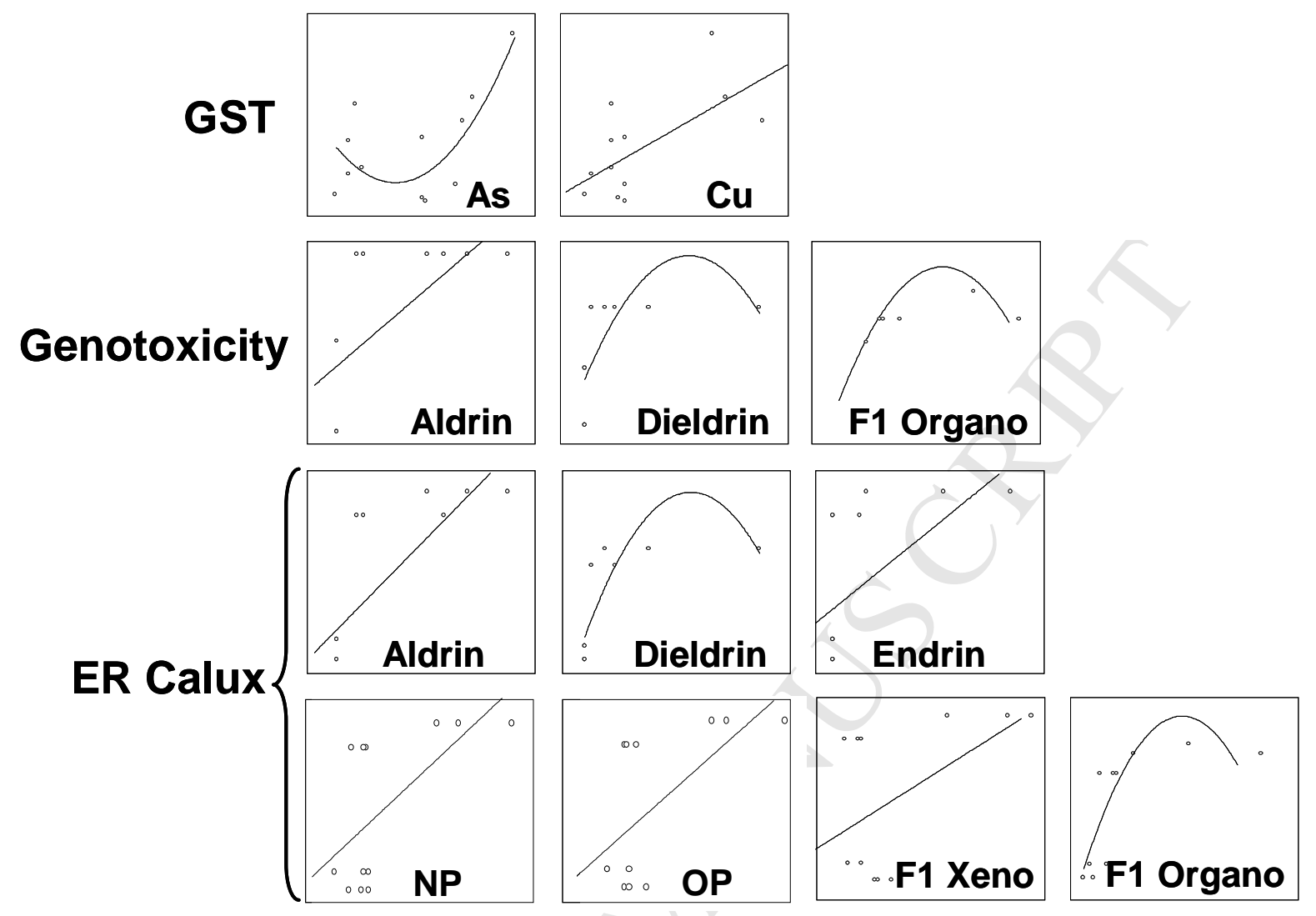


Fig. 7

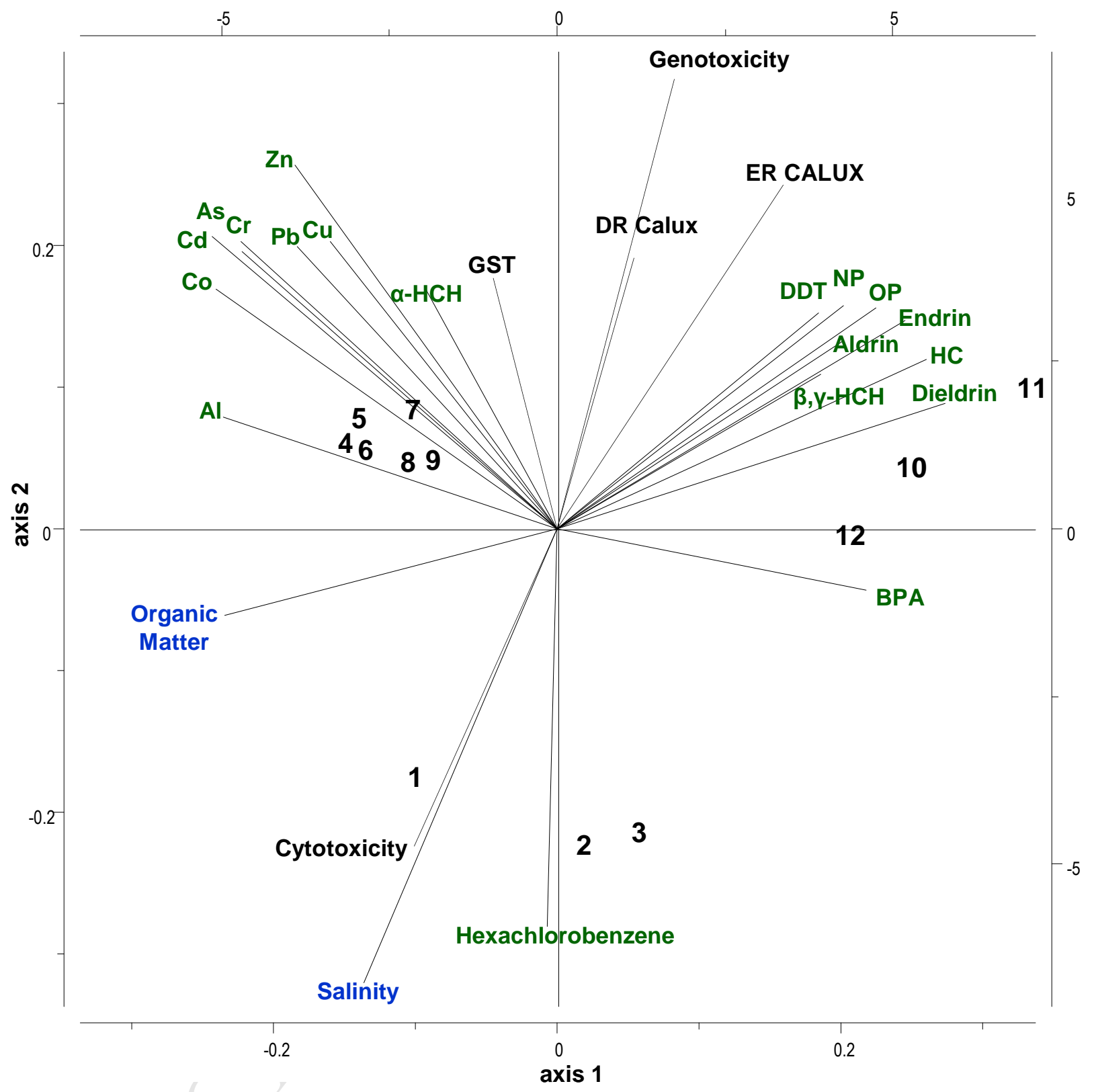




\section{Electronic supplementary material}

Table S1. Mean, median, minimum and maximum concentrations of metals and metalloids, PCBs, organochlorines, xeno-estrogens $\left(\mu \mathrm{g} \mathrm{g}^{-1}\right)$, genotoxicity and cytotoxicity (LEC in $\mathrm{g} \mathrm{ml}^{-1}$ ), DR-Calux (PCDD/F-PCB-TEQ $\mathrm{g}^{-1}$ ) and ER-Calux (pg EEQ $\mathrm{g}^{-1}$ ) of sediment; GST activity (nmol min $\mathrm{mg}^{-1}$ of protein) and organic matter content (\% of dry weight), in sediment and worms samples $(\mathrm{n}=12)$ collected at the Humber estuary. $<$ DL, below the quantitation limit.

\begin{tabular}{|c|c|c|c|c|c|}
\hline Chemicals & Names & Mean & Median & Minimum & Maximum \\
\hline \multirow[t]{9}{*}{ Elements } & Aluminium (Al) & 31790.95 & 32157.38 & 21241.54 & 43818.85 \\
\hline & Arsenic (As) & 10.53 & 10.97 & 7.60 & 14.62 \\
\hline & Cadmium (Cd) & 7.67 & 8.29 & 5.68 & 9.35 \\
\hline & Cobalt (Co) & 11.19 & 11.85 & 8.58 & 13.90 \\
\hline & Chromium (Cr) & 60.95 & 66.07 & 44.61 & 75.34 \\
\hline & Cooper $(\mathrm{Cu})$ & 33.54 & 28.59 & 19.67 & 62.60 \\
\hline & Lead $(\mathrm{Pb})$ & 64.70 & 56.83 & 38.46 & 125.51 \\
\hline & Zinc (Zn) & 148.38 & 141.17 & 90.45 & 227.32 \\
\hline & Nickel (Ni) & 29.47 & 31.19 & 21.76 & 39.05 \\
\hline \multirow[t]{8}{*}{ Organochlorines } & Alpha-HCH & 0.009 & $<\mathrm{DL}$ & $<\mathrm{DL}$ & 0.049 \\
\hline & Hexachlorobenzene & 0.045 & $<\mathrm{DL}$ & $<D L$ & 0.136 \\
\hline & beta- $\mathrm{HCH}+$ gamma-HCH & 0.005 & $<\mathrm{DL}$ & $<\mathrm{DL}$ & 0.032 \\
\hline & Heptachlor & 0.007 & 0.006 & $<\mathrm{DL}$ & 0.034 \\
\hline & Aldrin & 0.014 & $<\mathrm{DL}$ & $<\mathrm{DL}$ & 0.055 \\
\hline & 4,4-DDE + Dieldrin+2 & 0.009 & $<\mathrm{DL}$ & $<\mathrm{DL}$ & 0.062 \\
\hline & Endrin & 0.008 & $<\mathrm{DL}$ & $<\mathrm{DL}$ & 0.051 \\
\hline & 4,4-DDT & 0.009 & $<\mathrm{DL}$ & $<\mathrm{DL}$ & 0.062 \\
\hline \multirow[t]{3}{*}{ Xeno-estrogens } & Nonylphenol (NP) & 0.510 & 0.383 & 0.186 & 1.294 \\
\hline & Octylphenol (OP) & 0.050 & 0.033 & 0.019 & 0.138 \\
\hline & Bisphenol A (BPA) & 0.015 & 0.012 & 0.005 & 0.039 \\
\hline Biomarker & GST activity & 47.336 & 46.167 & 39.633 & 63.667 \\
\hline \multirow[t]{4}{*}{ Toxicity tests } & Genotoxicity & 0.0047 & 0.0085 & 0.01 & 0.0013 \\
\hline & Cytotoxicity & 0.0025 & 0.0025 & 0.005 & 0.0013 \\
\hline & DR Calux & 42.750 & 37.500 & 22.000 & 73.000 \\
\hline & ER Calux & 257.583 & 256.000 & 170.000 & 347.000 \\
\hline \multirow[t]{2}{*}{ Environmental } & Salinity & 7.89 & 6.84 & 1.96 & 19.78 \\
\hline & Organic matter & 8.926 & 9.157 & 5.982 & 12.189 \\
\hline
\end{tabular}


Figure S1. Correlation analyses within the elements found in the intertidal mudflat of the Humber estuary. Significant correlations $(\mathrm{p}<0.05)$ are shown with curves. Al, aluminium; As, arsenic; $\mathrm{Cd}$, cadmium; Co, cobalt; $\mathrm{Cr}$, chromium; $\mathrm{Cu}$, copper; $\mathrm{Pb}$, lead; $\mathrm{Zn}$, zinc and $\mathrm{Ni}$, nickel.

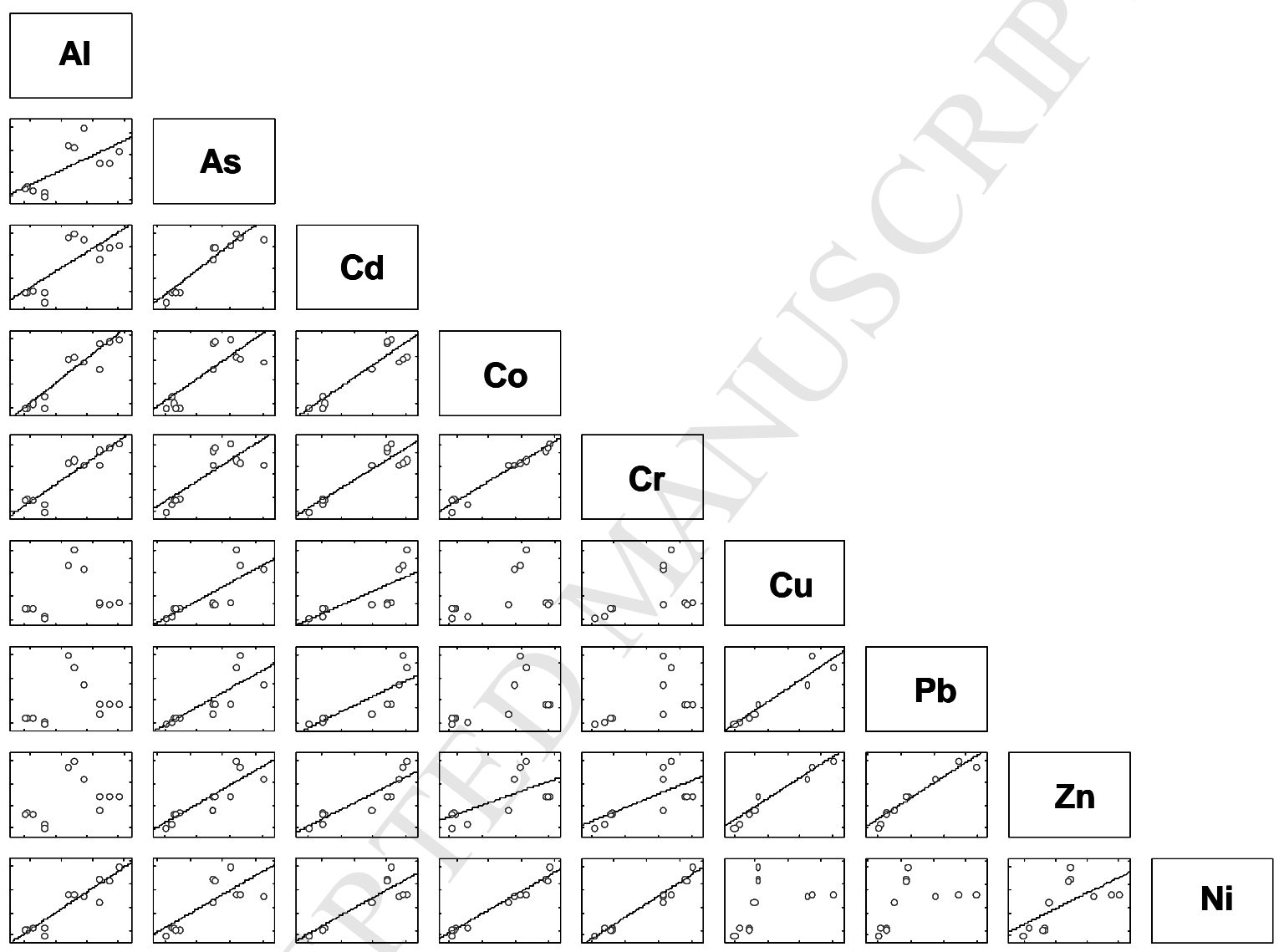


Figure S2. Correlation analyses between the organochlorines found in the intertidal mudflat of the Humber estuary. Significant correlations $(p<0.05)$ are shown with curves.

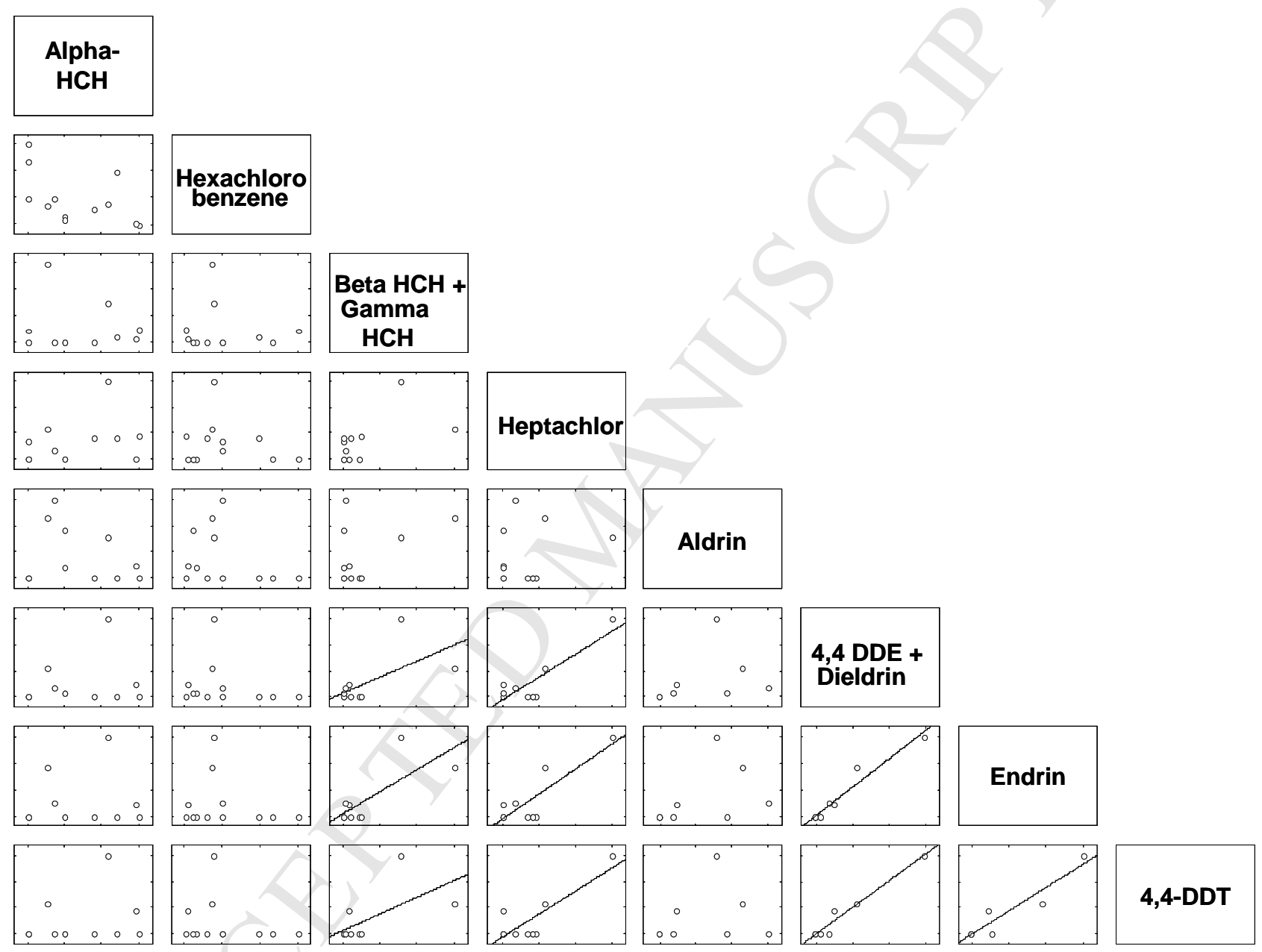


Figure S3. Correlation analyses between the organic and inorganic chemicasl found in the intertidal mudflat of the Humber estuary. Significant correlations $(\mathrm{p}<0.05)$ are shown with curves.

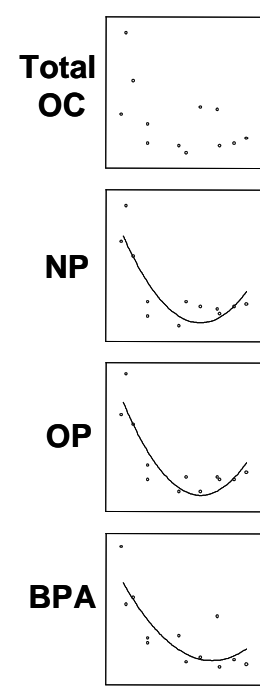

Al
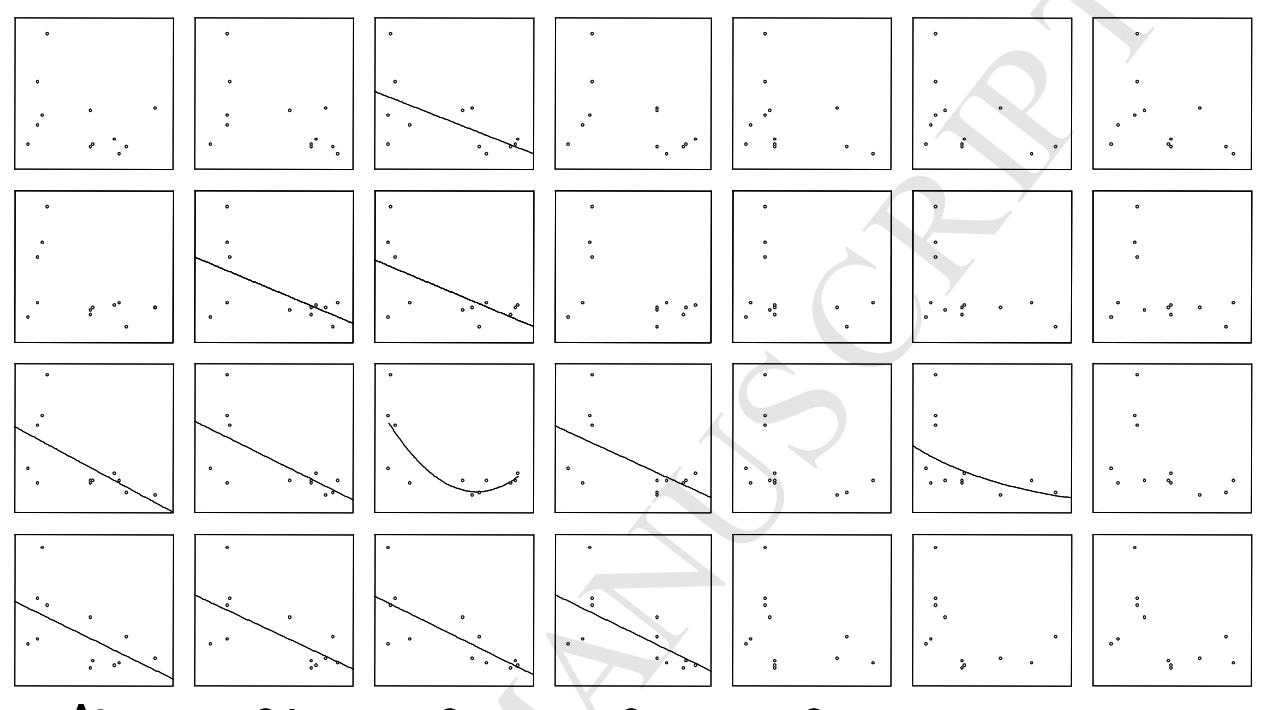

Cd

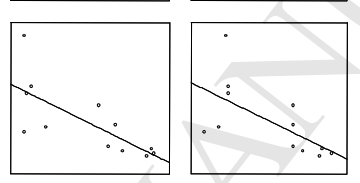

Co
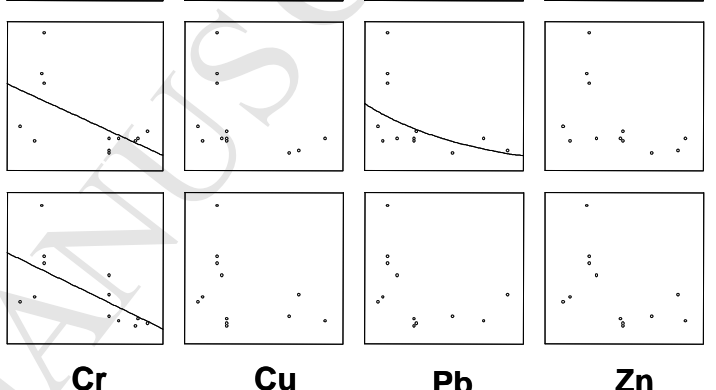

$\mathrm{Pb}$

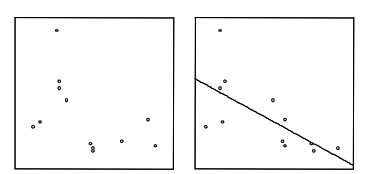

$\mathrm{Zn}$

$\mathrm{Ni}$ 